Article

\title{
Are There Moral Duties toward Refugees? Considerations in Legal Ethics
}

\author{
Paul Tiedemann
}

Citation: Tiedemann, Paul. 2021. Are There Moral Duties toward Refugees? Considerations in Legal Ethics. Laws 10: 4. https://doi.org/10.3390/ laws10010004

Received: 4 November 2020

Accepted: 30 December 2020

Published: 19 January 2021

Publisher's Note: MDPI stays neutral with regard to jurisdictional claims in published maps and institutional affiliations.

Copyright: (C) 2021 by the author Licensee MDPI, Basel, Switzerland. This article is an open access article distributed under the terms and conditions of the Creative Commons Attribution (CC BY) license (https:// creativecommons.org/licenses/by/ $4.0 /)$.
Öffentliches Recht und Europarecht, Justus-Liebig-University, 35394 Giessen, Germany; Paul.Tiedemann@recht.uni-giessen.de

\begin{abstract}
In the political and legal debate surrounding international refugee law, moral considerations play a large and important role. It often turns out, however, that the legal ethical reflection is not rooted deep enough. At first, it is necessary to demonstrate and justify the moral principle, on which the argumentation is based. There are different moral theories, among them the utilitarian, the egalitarian, the eudemonistical, and the deontological approach. These different approaches lead or at least can lead to different results concerning the question of what duties states or their citizens have toward refugees. The article is supposed to show that only the deontological approach is sufficient and appropriate in order to deliver a well-founded refugee ethics on the basis of moral duties and moral rights. The ethics of refugee protection is not an ethics of assistance to needy people, but the ethics of the prohibition of torts, namely, in particular, the violation of human rights. This is only inadequately reflected in international refugee law, because here the damage as such is not in the foreground, from which people flee, but the reasons why they are mistreated by persecutors. The damage-oriented approach clarifies the reasons for the different moral and legal status between persons in need of international protection, who have already reached the territory of the country of refuge and those who have not. The former are qualified as the holder of the subjective right not to be exposed to the dangers they have fled from, while the latter can in principle only appeal to the compassion and humanity of possible helpers. However, the boundary between "inside" and "outside" shifts according to the expansion of the de facto sphere of power of the acting person or state. This may also create a legal position for persons who are rescued by a ship at sea or whose living and travel conditions are essentially determined by the power of a state outside its territory. The damage-oriented approach shows furthermore that the refoulement ban has to be considered not only a mere side-aspect of the right to asylum but its core content. However, the right to asylum, cannot be considered a separate right beside the list of human rights. The refoulement ban is rather an integral part of every ("fundamental") human right. This shows on the one hand that the separate right to asylum is redundant as long as it is supposed to protect against human rights violations. It is relevant only in the context of protection on reasons of solidarity. Finally, it can be shown that the national and international case law concerning the refoulement ban is insufficient because it is focused only on threatening torture and inhuman and degrading treatment, meanwhile, it neglects the threatening violation of other ("fundamental") human rights.
\end{abstract}

Keywords: asylum paradox; deontological ethics; duty to rescue; egalitarianism; eudemonism; human rights; refoulement ban; solidarity; utilitarianism

\section{Introduction}

This essay is a contribution to legal ethics. It seeks to develop the foundation of the morality of refugee protection. Refugee protection is usually considered a public task that is fulfilled by states. It is, therefore, a matter of politics. The relation to politics suggests that refugee ethics should be conceived not as virtue ethics but as duty ethics. It is, therefore, a matter of whether and, if so, what moral obligations we have toward refugees and to what extent moral rights of the refugees correspond to these duties. 
Ethics deals with moral responsibility, which presupposes a conscience. However, only natural persons and no collectives have a conscience. From this follows that the state cannot be considered as the addressee of ethical requirements. Refugee ethics, therefore, turn not to the state, but to the individuals who work in and for the state (contrary: Funke 2017, p. 537 with further references). These are not just "the ones up there" who make the policy of a state, but all the individual citizens who can influence them through their participation in political processes. The state comes into play only through the question of whether and to what extent it allows its citizens and officials to act in accordance with morality, or whether and to what extent it expects its citizens and officials to act against morality and thus against their conscience.

Every ethical conception follows a certain fundamental theory, which is decisive for the contents of morality. I will, therefore, first discuss the moral theories in question (Section 2). The discussion of these different approaches does not imply the view that only one of these approaches would be "true" and all others "false". Each individual ethical approach is the most appropriate in certain contexts and not in others. It, therefore, depends on the exact conflict situation, for which an ethical solution is sought. We are e.g., not looking for the appropriate ethical approach to an ethic of fair distribution of burdens and profits among workers in a factory, nor are we looking for an approach to an ethic of the relationship of parents and children or to future generations. Rather, we are looking for the appropriate ethical approach for the ethics of refugees.

First, I investigate the utilitarian, the egalitarian, and the eudemonistical approach. All of them are not suitable for establishing a coherent refugee ethic. It can be shown that the deontological approach is the only appropriate basis for developing sufficient and convincing refugee ethics. In the center of deontological ethics stands the prohibition of damages. From this point of view, I am going to ask the question of which types of damage or harm is relevant to refugee ethics (Section 3). The worthiness to be protected against harming provokes the question of protective obligations and protective rights but does not yet answer this question. An answer to this question will be developed in Sections 4-6. In the course of this, I let myself be guided by the so-called asylum paradox (Endres de Oliveira 2016, p. 171). This refers to the peculiarity that under current law there is a claim for protection only for refugees who are already in the territory of the host country and not for those who are yet outside that country. The investigation follows this distinction and tries to clarify whether and to what extent it can be confirmed by moral philosophy.

This analysis tacitly assumes that states do not act morally wrong if they generally make the entry of foreigners into their territory subject to a formal license, and if they take the liberty to determine the material and formal criteria according to which the license is granted or denied. By accepting this axiom I reject the so-called no-border theory, which has recently received increasing attention and approval (Carens 1987, 2013, p. 225; Anderson et al. 2009; Mona 2007; Cassee 2016; Rochel 2020). ${ }^{1}$ I dealt with this postulate in another paper (Tiedemann 2017, 2018a).

\section{The Relevant Moral Theory}

\subsection{Utilitarianism}

The utilitarian moral theory refers to the principle that agents are always responsible for all the predictable consequences of their actions. It is less concerned about the consequences for those who have rights or claims by contract or warranty liability or for those who have an interest in not being harmed. Rather, he has in mind the consequences for the state, for the society, or for the world in general. This is why utilitarianism is often called a kind of consequentialism. ${ }^{2}$ Utilitarianism seeks to maximize the good in the world. Actions that help to bring about or to maximize the ultimate good are morally good, and

For a rather pragmatic critique of this approach cf. (Nida-Rümelin 2017b).

The notion "Consequentialism" in this meaning was introduced by (Anscombe 1958). 
acts that do the opposite are morally evil. There are no types of actions that are morally good in themselves and regardless of the context of the consequences for the world. Rather, a particular course of action in one situation may be morally optimal and, therefore, imperative, while in another situation it is sub-optimal and, therefore, prohibited (Trapp 1989, p. 124). Judging the consequences as good or evil depends on the good that is ultimately to be achieved. There are different ideas of what this good is. The most prevalent variant today is the conception of Preference Utilitarianism. An action is accordingly morally good if, with a view to realizing the preferences of all the subjects concerned, it produces a state of the world better than the state of the world which could be brought about by any alternative action (Trapp 1989, p. 132).

So, utilitarianism is, in fact, a theory of morality that can be considered as a candidate for the foundation of refugee ethics. However, what counts as morally relevant consequences is very often misunderstood. So, e.g., Konrad Ott believes that in the conflict between the interests of the refugees and the interests of the host country only the latter would count. Or that the latter at least would have a higher weight (Ott 2016; Ott and Riemann 2018). However, what really matters under utilitarian considerations is not the biased interests of the host society, but the best balance to be achieved, taking into account the preferences of all the subjects concerned. This results from the aggregated preferences of those whose particular interests would be affected by the state of the world in question (Trapp 1989, 133 et pass.).

The point is, first of all, to determine the subjective preferences of all those affected. This includes not only the preferences of the members of the host society but of course the preferences of the refugees. The preferences of third parties should also be taken into account, insofar as they are concerned. All these individual preferences must be aggregated, i.e., will be balanced against each other. In this calculation, the individual preferences do not take on the same weight, but they are to be weighted by the degree of concern. So, the interest in bare survival is more important than the interest in the availability of second homes or youth hostels, which must be made available for the accommodation of refugees (contrary Ott 2016, p. 63).

Finally, the weighted preferences are to be balanced in a way that achieves a world state better than that which could be achieved by a lesser or more commitment to refugees. So, it can prove to be morally correct that 1000 local people become unemployed while 1000 refugees take their jobs. For a state of the world in which 1000 people have work and no one has to fear for his life is better than a state in which 1000 people have work, but at the same time, 1000 people have to fear for their lives. ${ }^{3}$ As the example shows, utilitarianism can demand a substantial renunciation of particular interests, if this is necessary for the interest of the common good. So, utilitarian ethics can under circumstances demand moral heroism and complete selflessness of some involved.

The high demands of utilitarianism with regard to altruism and the individual willingness to sacrifice in favor of an optimal overall balance exists toward all involved, including the refugees. If one accepts the utilitarian approach, it follows at least for the question of this essay: There are no obligations that we must fulfill towards individual refugees, at least no obligations that correspond to subjective rights of refugees. For it would not matter whether or not a particular refugee is rescued. Relevant would be only whether the state of the world affairs, in general, is improved. There would be a duty toward the world but not a duty toward refugees.

This is very contrary to our usual inclinations. Therefore, the justification of altruistic utilitarianism requires very strong arguments. Peter Singer justifies the utilitarian position by pointing out that ethics as such requires us to go beyond ' $\mathrm{I}$ ' and 'You' to a universal judgment to be taken from the point of view of the impartial observer (Singer 2011, p. 11). His moral theory is, therefore, purely analytically grounded. He derives it from a very

3 A more concrete variant of this consequentialist refugee ethic based on the example of Australia is provided by Peter Singer, in Singer (1993). Neither the 1 st nor the 3rd edition contains this chapter. 
specific concept of ethics: ethics is taking the impartial point of view. Thus, a biased viewpoint, which refers to real individuals, is by definition unethical. This is obviously not a justification, but a mere circular conclusion. Singer himself seems to see the problem, but he takes it only indirectly into account by replacing the actual utilitarian duties through milder duties which are limited by the criterion of reasonableness (Singer 1972, p. 235). This "mitigation" of utilitarian duties is due to our moral intuitions, but it cannot be integrated argumentatively into the system of the utilitarian approach. ${ }^{4}$

The search for a justification of altruistic utilitarianism remains fruitless. There is no reason why people should be ready to let themselves offset in the interest of optimal states of world affairs (McNauthton and Rawling 1998, p. 42). The reason why this moral theory is nevertheless so popular among utilitarian philosophers seems to be that they only ever look at the (moral) world from the outside. They do not see themselves as moral agents, but as outside observers and uninvolved managers of world affairs (Trapp 1989, p. 140). ${ }^{5}$ It is an agent-neutral moral theory. ${ }^{6}$ From the perspective of a person who understands himself as a participant, as an agent, and affected by moral life, this moral theory is only plausible if he believes in objective values that are somehow predetermined and under whose rule he stands. This cannot be done without very strong metaphysical assumptions. That's why Thomas Nagel recommends "to resist the voracity of the objective appetite" and to take a subjective view (Nagel 2000, p. 211).

\subsection{Egalitarianism}

A clearly subjective approach is represented by the so-called egalitarianism. This ethical conception assumes that every human being has a moral right to exactly the same chances and opportunities to develop his life as every other human being. The allocation or acceptance of unequal life chances is only justified in exceptional cases, and only if there are strong rational reasons for unequal treatment. An argument is recognized as a strong rational reason only if it can be accepted also by the respective disadvantaged persons (as long as they think rationally). In contrast, the principle of equal treatment does not need to be further justified. It is regarded as self-evident. The basic axiom of egalitarian ethics is therefore the presumption of equality or the principle of presumptive equality.

Egalitarians argue that people in need of protection would never rationally accept any argument that excludes them from the needed protection (Märker and Schlothfeldt 2002; Ladwig 2011, p. 81; Ladwig 2012, p. 72). It follows from this that every human being in need of help and protection has a moral right to support and protection which they can assert against the state to which they have fled or which can actually save them.

This argument stands or falls with the power of persuasion of the principle of presumption of equality. Ernst Tugendhat is one of its prominent defenders. He bases this rule on the idea that the presumption of equality is unavoidable, that is, compelling. He wants to make this clear by the example of the distribution of a cake among several children (Tugendhat 1997, p. 373). There may be, Tugendhat says, different reasons for an unequal distribution. However, if no relevant reason can be given, then only the egalitarian distribution remains. This results from the fact that there are no reasons to distribute unequally. A primary justification for the presumption of equality is not needed. There is simply no alternative if there are no reasons for an unequal distribution. Therefore, we should only ask for reasons for inequality but not for equality. In the absence of relevant reasons for inequality, there is only one alternative to equal distribution, namely arbitrary distribution.

4 In addition, its standards of reasonableness do not meet the requirements that would have to be met in the interest of a self-determined autonomous life, cf. (Steinvorth 2008, p. 181).

5 Otherwise, it cannot be explained why utilitarianist philosophers can reach a high age alive and well, although a sober calculation of the best state of the world should have led them to donate their vital organs to a large number of people at a young age who have been dying because of a lack of these organs. The prominent Australian utilitarian Peter Singer is said to have made it possible for his demented mother to have a good life in an excellent nursing home at great financial expense. In an interview, he declared that this behavior was wrong according to the standards of utilitarianism. This suggests that Singer only represents the utilitarian approach if he is not affected himself-cf. (Schnabel 1999).

6 The distinction between actor-neutral and actor-related ethics goes back to (Derek Parfit 1984). 
Arbitrariness is, according to Tugendhat, the counter-concept to justice. Therefore, before any distribution, the question must first be clarified, whether it should be arbitrary or fair. If one decides for fairness and justice, then one enters "the area of the equal".

It remains unclear whether Tugendhat understands the presumption of equality as a universal moral principle. Some of his statements speak in favor of a non-universal application. So, Tugendhat points out whether "a society understands itself in principle as a community of goods. Only in this case must be spoken about a fair or unfair distribution of material goods." (Tugendhat 1997, p. 381) Justice in the sense of equality is, according to Tugendhat, thus always about justice within a particular community. It does not concern the question of access to a community. This is also shown by his cake example. He opens this thought experiment with the words: "If a cake is to be distributed among several children, [then the following applies ... ]" (Tugendhat 1997, p. 373). Already this introduction implies that a cake does not have to be distributed among all children in the world, but only among the children sitting at the table.

Bernd Ladwig, however, not only refer to the question of the distribution of burdens and profits within a previously defined community based on cooperation or solidarity, but instead assigns universal validity to this principle. In support of the universal reach of the principle of equality, he points to the same moral value of all human beings. From this same moral value of all human beings follows, according to Ladwig, that everyone's life, well-being, and self-determination are morally equally important, so that the unequal distribution of life chances must be justified in relation to each affected person. If such a justification is not possible, then it remains only equal distribution (Ladwig 2012, pp. 72, 73; Gosepath 2003, p. 285).

Yet, what justifies the claim that all human beings have the same moral value? Egalitarianism denies that there are absolute rights or an absolute status. For egalitarians, all conceivable protected goods of human rights are initially only objects of subjective desires. The unfulfillment of subjective desires does not constitute a moral issue from an egalitarian point of view, because mere wishes as such are not relevant in terms of morality. Only when it turns out that subjective wishes are unequally fulfilled does egalitarianism face a moral problem that must be solved according to the principles of distributive justice (Gosepath 2003, p. 279).

If there are no absolute rights of individual persons but only a relative right to equal treatment, then respect for the moral value of the person as such cannot be considered the content of a right that every human being possesses simply because he/she is a human being. Egalitarianism makes an attempt to generate the value of the person from the principle of equal distribution. However, before one can think about the equal or unequal distribution of values and goods, they must first exist. One cannot create them through equal distribution. Egalitarianism is therefore forced to presuppose the moral value of the person already before distributing it according to the principle of equality. Thus, it must already presuppose what it then tries to justify by the principle of equality. It is easy to see that egalitarianism is entangled here in a petitio principii. In the absence of absolute subjective rights, Stefan Gosepath introduces the claim of an "egalitarian plateau" upon which all present moral theories moved (Gosepath 2003, p. 285). He thus avoids the petitio principii by asserting a moral-philosophical commonsense that is independent of the principle of equality. This commonsense assumes the function of an absolute starting point of his argument, but, at the same time, compels him to deny his arguments against a non-relative source of moral rights. What people owe each other for respecting their equal moral value is expressed in the human rights that are absolute subjective rights. The egalitarian approach does not accept absolute subjective rights. Thus, it cannot answer the question of whether there is a human right to be rescued when in need of protection.

\subsection{Eudemonism}

So, there are no good reasons for a utilitarian or an egalitarian foundation of refugee ethics. When looking for an alternative it makes sense to pay some attention to what was 
in ancient ethics called the eudemonistical approach. While the utilitarian approach can be called altruistic - it focuses on the well-being of the entire world-the eudemonistic approach focuses on the well-being of the moral agent. However, eudemonism is not egoism or selfishness. It does not give absolute priority to one's own interests while disregarding the well-being of others. Egoism is usually not identified with a particular moral theory, but rather held to be the opposite of morality, that is, simply immoral. In contrast, eudemonism means a serious moral theory, which has a long tradition and was especially without an alternative in antiquity.

The goal of ancient ethics was the happiness of a good and successful life, Greek: $\varepsilon v \delta \alpha \iota$ oví (Obermayer 2017). Whoever does what is due to fellow humans and to the gods, who is just and pious, will, according to Platon, lead a blissful life (Platon 1966a, Gorgias 507b-e; 1966b, Politeia 353d-354a). In antique ethics, it is ultimately not about the well-being of others or about the best state of the world, but about the best state of the acting subject. This occurs when the subject attains bliss. However, this state can only be achieved if the person satisfies religious as well as moral standards. The well-being of others is, therefore, not indifferent to the ancient individual striving for happiness. Rather, the ancient person knows that in the interest of their own happiness they must also take consideration of others and may not be indifferent to their fate. In the end, it's not about the interests of others, but about my life (Bayertz 2014, p. 35). With such an objective, the requirement of self-sacrifice or the status of the subject as a mere accounting unit is incompatible.

The care for one's own successful life is today (again) an important theme of philosophical ethics. In contrast to the perspective of the ancient world, today it is assumed that eudaimonia cannot be attained by assimilating objectively prescribed values and principles of the worthy, but rather by autonomy (Rössler 2017). A person reaches eudaimonia through the deeply felt experience of living his own life. ${ }^{7}$ Only those who experience themselves as the author of their life can experience their life as meaningful (Rössler 2017, 96 et pass.). They perceive themselves not merely as something (= self-alienated), but as somebody (=authentic). Autonomy requires the freedom to pursue one's own life projects. Life projects are all projects, plans, relationships, or obligations that a person has chosen for themselves (Rössler 2017, p. 43). The choice itself is authentic if it is based on one's own reasons, that is, on one's own reflections and considerations, and not on the extortion or manipulation of others (Rössler 2017, p. 50).

It is incompatible with the idea of autonomy if a person can devote his life predominantly or even completely not to his own life projects, but is rather coerced to serve the life projects of others (Nida-Rümelin 2017a, p. 36). Even Kant considered such a surrender of self-interest in favor of foreign interest to be immoral because the individual himself must not make himself a mere means for the purposes of others (Kant 1797, pp. 26, 30). Thus, according to Kant, human beings have duties not only to others but also to themselves (Kant 1797, p. 42). These duties include moral self-esteem, which forbids being humble in the wrong way, and "fawning" and "servile" behavior (Kant 1797, 94 et pass.). This is the case when one puts oneself entirely at the service of the interests of others, that is, assumes an altruistic attitude to life. The contemporary ethics of felicitous life also consider autonomy as a normative concept, that is, as an obligation that must be fulfilled in relation to oneself (Rössler 2017, p. 237).

Thus, there is a counter-position to utilitarian altruism, which emphasizes the moral duty of individuals not to exploit themselves for the projects of others but to operate their own projects. Of course, these own projects should also include caring for others. However, it must be self-elected, not morally prescribed, or heteronomously coerced. The

7 The idea of autonomy goes back to Kant, namely his idea that humans should live by the laws they have given themselves. For Kant humans are autonomous only if they act morally, i.e., according to maxims for which they can want that they become a universal law (moral autonomy). John Stuart Mill has broadened the idea of autonomy beyond this purely moral meaning. According to him it is about the freedom to do and to omit whatever one wants to do or to omit, as long as one does not harm anyone (personal autonomy). Mill has taken over this idea from Wilhelm von Humboldt and his idea of the free development of the personality. Cf. (Kant 1786, p. 79; Mill [1859] 2001, p. 54). 
felicitous life, in the sense of an autonomous life, has a moral value of its own. ${ }^{8}$ According to the eudemonistic approach, therefore, it cannot be required that a person completely disregards their own interests and considers oneself as a unit of accounting. Accordingly, selflessness, in this sense, is not a moral virtue, but on the contrary an expression of an immoral attitude of self-humiliation.

Eudemonistic ethics prohibits selflessness and self-sacrificing in favor of the interests of others but at the same time, it prohibits crude egoism and ruthlessness. The truth is somewhere between these two extreme positions. In this interstice of possibilities, many forms of life are imaginable, which, in different ways, place the emphasis on me and the others. All these life forms are morally justifiable. The pursuit of autonomy, on the one hand, and the pursuit of a character, on the other hand, that is coined by goodwill toward other people and the strong impulse to help people in need, are the goals of an ethic that strives for the perfection of each moral subject. Kant described this aspiration as a duty to themselves and as a duty of virtue (Kant 1797, p. 26 et pass.). He distinguishes this kind of duty from the "legal" duties. This does not necessarily mean juridical duties, but rather also moral duties that exist toward others and whose violation can, therefore, be sanctioned by others. These (moral) legal obligations correspond to corresponding (moral) rights, which are directed to the fulfillment of the duties.

As stated at the beginning, this study is concerned with the ethics of duty and not with the ethics of virtue. Duties toward oneself (virtue duties) do not matter here. For virtue ethics can contribute nothing to an ethic of refugee protection, which to clarify is what we owe refugees, and what refugees may demand of us. However, whatever refugees demand, it cannot infringe the autonomy but has always to be in accordance with the autonomy of the moral agent.

\subsection{Deontological Ethics}

In today's moral-philosophical debate, it is rare for eudemonism to be seen as an alternative to utilitarianism. Instead, the deontological theory of morality is considered a relevant alternative. Deontology (from $\tau o \delta \varepsilon o v=$ duty) is understood as a moral theory according to which moral norms do not contain goals for certain extra-moral values (subjective autonomy/improvement of the world) but concrete imperative instructions in the form of a prohibition or a commandment. ${ }^{9}$ Accordingly, one should, for example, keep a promise solely because it is intrinsically correct to keep a promise, not because it improves the state of the world. Of course, this is also about the consequences of actions. What is relevant, however, is not the consequences for the state of the world affairs in general or the successful life of the agent, but only the consequences for those who are entitled and obliged from the respective prohibitions or commandments (McNauthton and Rawling 1998). In the center of the deontological moral theory stands only one general rule:

Rule 1: Do not harm anyone!

(It is prohibited to harm anyone.)

Anyone who violates this rule and inflicts injury on another person thereby generates a special obligation toward the injured party, by virtue of which he now must take responsibility for certain interests of the injured party. This special obligation is called the guarantor position. The particular interest of the injured party, for which the tortfeasor is responsible, is the elimination of the compensation of the damage. This results in the second rule of deontological moral theory:

Rule 2: Pay compensation if you have violated rule 1!

(It is commanded to compensate for the damage if rule 1 has been violated.)

For the sake of completeness, it should be mentioned that a guarantor position cannot only be generated by an act of harming. It can also result from an act of voluntary takeover.

8 Ultimately, it is about this intrinsic value of successful life. Eudemonism is therefore not a duty ethics but a value ethics. However, duties can be deduced from the relevant values. On the primacy of values and their relation in an axiological ethic contrary to a duty ethics cf. (Lumer 2004).

9 The differentiation between deontological and teleological moral theories was introduced by (Charlie Dunbar Broad [1930] 2001). 
This is the case when concluding a contract, by which the contracting parties are placed in a guarantor position by virtue of which they are obliged to render the contractually owed to the other party. Guarantor positions also arise through appropriate moral attributions. For example, parents have certain guarantor positions towards their own children. ${ }^{10}$ However, in the context of refugee ethics, these particular types of guarantor obligations are normally irrelevant and can, therefore, be neglected below. It is enough to keep an eye on the two rules mentioned above.

These two rules are still very vague because they leave open what is meant by harm. Despite this indeterminacy, however, they already show that the deontological moral theory differs in one important respect from the moral theories studied so far. It only tells us in a very special case what we should do, namely, in the case that we have violated rule 1. In this case, it is clear what to do, namely, to pay damages. In any other case, this moral theory does not say what we should do or in which direction our life should go. It does not, like utilitarianism, demand to improve the state of world affairs by positive acting. Rather, it just tells us what we are not allowed to do, namely, harming others. So, the deontological approach to ethics recognizes and respects the autonomy of the moral agent. Moral agents are free to lead their life on the basis of free chosen life plans, even if these plans do nothing to contribute to the improvement of the world. In contrast, utilitarianism accepts only those life plans, which are productive for the improvement of the world. One can also say it this way: deontological ethics accept life in privacy, while utilitarianism obliges to a public life that is always dedicated to the common good. This is a huge difference between utilitarianism and deontology.

The crucial point of the deontological moral theory becomes apparent if it is not seen as an alternative to eudemonism and utilitarianism but as a kind of modification. ${ }^{11}$ As such, it is capable of limiting both the commitment to the benefit of oneself and the commitment to the benefit of others or of the state of world affairs. The categorical imperative of deontologically modified eudemonism is then: Lead your own life, but do not harm anyone! The categorical imperative of deontologically modified utilitarianism is: Improve the world, but do not harm anyone!

With regard to the handling of refugees according to the deontological moral theory, the prohibition of damage is in the foreground and not any obligations to render aid. ${ }^{12}$ In other words, by dealing with refugees we can do or omit what we want, as long as we do not harm anyone. That sounds harmless at first. However, it will be shown that the prohibition of damage is of the utmost relevance in refugee ethics. Before this relevance can be understood, it must first be clarified what is meant by (morally relevant) harm.

\section{The Relevant Distress}

The prohibition of harming remains free of content unless it is determined what is to be understood as harm. Not every addition of a disadvantage (e.g., defeating the opposing football team) is an act of harming because it does not consist in inflicting morally relevant harm. Therefore, we can only speak of harm if the disadvantage consists of the impairment of morally relevant goods.

A good is morally relevant if two conditions are met: (1) It must be a good that is recognized as valuable not only by the potentially injured party but also by the potential offender. (2) It must be good, relating to which it is valuable for us that others enjoy them. Otherwise, they are goods based on mere subjective preferences that we do not need to worry about. So, it is about goods for which we are interested in others having. If the situation in which a stranger is distinguished by the lack of (sufficient) access to goods that

10 However, according to Section 323c of the German Penal Code the failure to render assistance is put under penalty especially in cases where there is no guarantor position. But this is a norm of positive law, which is morally not compelling. The European tradition of penalizing failure to render assistance outside of a specific guarantor obligation may be linked to a specific understanding of community (in the sense of Tönnies) and the resulting solidarity. In legal cultures, which are more individualistic like the US, such a norm is rather rare. Cf. (Rosenbaum 2011, p. 246).

11 I owe this view to (Schroth 2009, 55 et pass.).

12 See the debate between (Brezger 2016; Hoesch 2016). See also (Funke 2017, p. 539). 
are morally relevant to us in this sense, the question of protection and support becomes a matter of moral relevance. The situation is to consider moral standards. We are called to moral considerations.

There are three different categories of goods that are morally relevant in terms of refugee ethics. These are, first of all, those goods that are protected by human rights or at least by a part of human rights ("fundamental" human rights). These goods are hereafter called HR-goods. The second category of goods concerns those in relation to which we feel solidarity with persons (solidarity goods). Finally, there is a third category of goods in which we have a moral conviction that other people should have access to them, even though they are neither HR-goods nor solidarity goods. These are goods to which we apply the Golden Rule. We believe that we should not harm others in access to these goods because we do not want to be harmed ourselves even with regard to goods of this type. I call these goods justice goods. Typically, these goods include access to resources that human beings use to earn a livelihood and adequate wealth if the loss of these resources does not lead to the deprivation of the subsistence level and thus to human rights-related harm.

\subsection{The Relevance of HR-Goods}

First of all, it has to be explained why the suffering of a shortage of HR-goods by another person is morally relevant for us. I can only make this sketchy. For a more detailed argumentation, I have to refer to other publications (Tiedemann 2020, 79 et pass.).

HR-goods are only those required to develop and maintain personhood. The codified human rights catalogs also contain numerous rights, which do not apply to HR-goods in this sense (e.g., right to free movement, right to property, right to paid annual vacation). However, only such rights can be grounded as human rights in moral philosophy, which refers to the protection of the conditions of personhood. Personhood is the ability of a subject to develop its own (authentic) will on the basis of its own considerations and reflections. The will prescribes the maxims according to which the subject can lead their own life. Only if the will is based on its own considerations and reflections can we consider it as authentic. HR-goods, therefore, refer to the freedom of the will from any kind of oppression, self-alienation, and manipulation. On the other hand, they do not refer to the freedom of action (for example, the freedom of robbing a bank, driving on the left instead of on the right, riding in the woods, drinking alcohol after 11 a.m., etc.). Restrictions on the freedom of action do not normally threaten personhood. Personhood, on the other hand, is threatened when someone is brought to mortal fear, tortured, or similarly exposed to physical or mental suffering. Such impairments deprive a person of the ability to create their own will based on their own considerations and reflections. Personhood is threatened furthermore where the process of will making is manipulated by false information or by suppressing intellectual articulation. Personhood is finally threatened, where the person is under permanent external control because of a lack of private retreat and, therefore, cannot come to oneself.

Personhood as the ability to form one's own authentic will has an absolute value for every person. For it is the condition of the possibility of any evaluation. Under no circumstances can anything be more valuable and preferable for a person than their own personhood. Immanuel Kant introduced the term dignity for the concept of absolute value, which he distinguishes from price as the notion for relative values (Kant 1786, p. 77). Personhood is the only entity to which dignity can be assigned. ${ }^{13}$ Human individuals live under inhumane living conditions when these conditions are characterized by the fact that under these conditions it is much harder or even impossible to develop and sustain personhood.

The personhood of a person is an absolute value not only for them but also for every other person. This does not follow from the fact that every person can empathize with

13 Insofar as Human Dignity is understood as an absolute value, it can only refer to the dignity of the person. 
others. ${ }^{14}$ Rather, the actual reason is that the personhood of the others is the condition of the possibility of one's own personhood. It follows from this principle of the equiprimordiality of one's own and another's personhood that we can neither perceive nor value our own personhood absolutely unless we simultaneously perceive and absolutely value the personhood of the others. This recognition and appreciation do not only apply to the close circle of caregivers, without which one's own development to a person is necessarily deficient and must end in serious deformations and disturbances. Rather, the recognition and appreciation must refer to all persons who exist at all, because it is impossible to value the personhood of caregivers absolutely without appreciating the personal value of all persons absolutely. ${ }^{15}$ Therefore, we perceive the loss or the threatening loss of other person's personhood as morally relevant, and any act that results in such loss as an act of harming.

The equiprimordiality-theorem of human dignity does not allow any relevant differentiation between inhumane living conditions that are caused by men (anthropogenically) and those that are caused by nature (physiologically). Rather, the need for protection of all persons seeking to escape inhumane circumstances is of equal moral importance, whether based on anthropogenic persecution or treatment, or natural disasters for which no human being can be blamed. The only decisive factor is the loss or impairment of the personhood and not the causes of this impairment. From this approach, it is morally irrelevant whether people flee from an (anthropogenic) violation of human rights. The only relevant factor is whether, in the event of their return to their home country, they run the risk of suffering a shortage of an HR-good. All goods protected by human rights (life, integrity, freedom of thought, privacy, etc.) are partial aspects of that good, which ultimately concerns human rights, namely, personhood.

This result deviates fundamentally from the requirements of conventional refugee law. According to this, only those refugees who have escaped targeted acts of persecution or at least the serious threat of inhumane treatment, in other words: those who have suffered anthropogenic damage, are considered worthy of protection. The lack of understanding for the proposal for a refugee convention for climate refugees is correspondingly high (Myers 2002; Shamsuddoha 2009; Collins-Chobanian et al. 2010; Bedarff and Jakobeit 2017; Ott and Riemann 2018).

Since personhood is of absolute value, refugee-ethical relevance depends solely on whether there is serious impairment in HR-goods. There is no need for further circumstances, nor are reservations or forfeiture acceptable. There is, therefore, no moralphilosophical justification for the regulation in Art. $1 \mathrm{~F}$ of the Geneva Refugee Convention (GRC), according to which among others war criminals are excluded from refugee protection. If they are at risk to lose HR-goods, they are from a moral point of view worthy of protection. ${ }^{16}$ They are human beings and human beings are the bearer of human rights. Human rights cannot be forfeit because even war criminals do not cease to be human beings.

On the other hand, however, this means that unfortunate situations below the level of serious impairment of basic human rights are not relevant to refugee ethics unless they fall into one of the two categories of morally relevant goods yet to be discussed. This finding is in striking contrast to the description of persecutory acts in European positive law. In addition to serious human rights violations, the relevant EU directive also recognizes the "accumulation of various measures" as persecution that can do without any human rights violations, but are "sufficiently severe as to affect individuals in a similar manner". ${ }^{17}$ This is

14 See, however, the argumentation on the basis of the so-called Capability Approach, as it is represented by Martha Nussbaum (2011).

15 These relationships cannot be developed here in detail. See therefore (Tiedemann 2020).

16 According to Art. 1 GRC, persons are excluded from refugee protection who have committed war crimes or crimes against peace and against humanity, as well as serious civil crimes abroad or have committed acts contrary to the purposes and principles of the United Nations. While there is no moral justification of the exclusion of such offenders from the right to be protected, nothing prevents the host state from bringing these people to justice.

17 Article 9 para 1 lit. b Directive 2011/95/EU of 13.12.2011-OJ EU No. L 337, p. 9 (in short: QD) 
then specified in three variations. All these variants refer to certain ways of discriminating by public measures and the disproportionate nature of punishment. ${ }^{18}$

Discrimination consists of putting certain individuals at a disadvantage compared with other individuals. It is the other side of privilege. Discrimination and privilege do not refer to objective standards of ensuring HR-goods, but only to relative equal treatment. According to this standard, torture is unproblematic, as long as only all are tortured in equal measure. However, this is just as absurd as considering the Nazi persecution of the Jews as a case of mere discrimination (But contrary: Rennert 2017, p. 27). There is no moral reason to consider foreigners in general deserving of protection because they are being discriminated against. This is true even if some individuals, unlike others, cannot make academic or political careers for irrelevant reasons, have to pay more taxes, have to endure more police checks and official harassment, or are not allowed to drive.

What applies to discrimination also applies to disproportionate punishments. There are no objective standards for a substantiated relation between crime and sentence. Therefore, it is only necessary to ask whether a punishment is relevant to human rights. This is the case if it consists in the deprivation of life, in the infliction of sustained physical sufferings and disabilities, or if the punishment, in terms of its nature and duration, is capable of sustainably damaging or destroying the personhood of those affected.

At the same time, it is clear from these considerations that sentences of imprisonment are conceivable which, according to their type and duration, do not jeopardize the personhood and are, therefore, not relevant as such in terms of refugee ethics. Threatening placement in a detention center as such does not provide any obvious morally relevant reason for fleeing, because detention is also in the arsenal of legitimate state power in host countries. Deprivation of liberty is considered to be compatible with the moral standards of human rights, as long as the detention center does not have the characteristics of a total institution in which the inmates' personhood is destroyed and as long as all other conditions for a decent life are secured..$^{19}$ One can of course question whether such dignitycompatible conditions in a prison can be met at all. However, this question needs not to be dealt with here because it does not result in any specific consequences for refugee ethics. If prisons are always a violation of human rights, then they must be abolished. Or domestic prisons allow decent imprisonment, then this is basically also possible in foreign countries. On the other hand, it would not be plausible to give protection to people fleeing foreign detention without regard to the nature of the conditions of detention and to continue to detain offenders domestically.

\subsection{The Relevance of Solidarity}

In the classic positive refugee law, a person is recognized as a refugee only if they have fled for reasons of fear of persecution "because of race, religion, nationality, membership of a particular social group or because of their political opinion" (Article 1 A 2 GRC). ${ }^{20}$ These so-called persecution grounds are far more important to the question of granting refugee protection than the nature and severity of the predicament that those affected want to escape. Therefore, a violation of fundamental human rights is considered irrelevant by refugee law if the persecution is unrelated to the said reasons. For example, threatening torture alone does not lead to refugee protection under the GRC if the torture is not threatened because of political opinion or religion, etc. On the other hand, however, refugee protection is already opened when the threat of impairment consists only of

18 Article. 9 para. 2 lit. b-d QD. Litera e and f do not deal with the description of acts of persecution but with specific reasons of persecution. Litera a) defines partially severe violations of human rights as physical and psychical violence including sexual violence.

19 For the characteristics of total institutions cf. Goffman (1961); generally for decent detention conditions cf. (Krammer 2012; Strohmayr 1998).

20 The history of the classic positive refugee law begins with the English Aliens Act of 1905 and today finds its universal expression in the Geneva Refugee Convention of 1951. For the history of refugee law cf. Tiedemann (2016a). 
discrimination or imprisonment under decent circumstances, but that there is a connection with the above-mentioned persecution grounds. ${ }^{21}$

With regard to refugee ethics, reasons for persecution cannot play a role when it comes to serious impairment in HR-goods. For in these cases, the threat of damage as such justifies the moral relevance of the request for protection. Insofar as the positive refugee law refuses to grant protection despite human rights damage if there are no grounds for persecution, this is ethically unjustifiable, as stated in the first section. ${ }^{22}$

There is still another question: Are there ethical reasons to consider protection claims of asylum seekers morally relevant if they are not at risk of being impaired in HR-goods, but are persecuted for one of the reasons mentioned above. Let us think about person A, who because of their commitment to the rule of law and democracy in their authoritariangoverned home state, is threatened by (decent) imprisonment and has, therefore, fled. Why should the protection claim of A be ethically relevant if there is no threat of a violation of human rights?

A conditional connection of equiprimordiality, as it exists in respect of human dignity and human rights, does not play a role here. Democracy and the rule of law are high values for us as well. Therefore, we feel some sympathy for people who work for these values in other countries. However, the question is whether this value attitude of other people compels us to take their request for protection morally seriously.

An answer to this question can be gained through the concept of solidarity (Tiedemann 2018c). According to Simon Derpmann, solidarity is the cause of certain moral obligations that result from affiliation or membership. Awareness of affiliation is based on the individual normative self-understanding, insofar as humans make something of themselves essential to themselves that they share with others, and by which they are made members of a community. This community-based self-image creates specific reasons for action with regard to the members of that community, which are understood by all members of the community as duties to which rights are related (Derpmann 2013, p. 12). Based on their solidarity, people confirm what they stand for and what they cannot give up without damaging their self-image. Solidarity requires the awareness of a common matter of all members of the community of solidarity. This common matter can, among others, consist of a common history or in the consensus of a decent society (Derpmann 2013, p. 29).

But how can shared ideas of a decent society be a common matter in this sense? Hereupon the theorem of cognitive dissonance offers an adequate answer. Even the most confident and dedicated democrats sometimes doubt the value of democracy, for example, when they observe how easily populist demagogues succeed in abusing democratic institutions. Similarly, there are doubts about the value of the rule of law, which can sometimes stalk us, if we have to endure obvious criminals getting away for formal reasons (such as the statute of limitations). Such doubts about values that are identity-building for a confident democrat trigger what Leon Festinger called cognitive dissonance (Festinger 1957). It is a specific mental discomfort caused by uncertainty as to whether we identify with the right values at all. Such doubts are frightening because they are linked to an impending loss of orientation for the future.

The quiet doubt is the constant companion of our basic values. We could only avoid it for the price of fundamentalist madness and ideological stupidity. Therefore, we gratefully reach for anything that confirms our values and dispels doubts. This confirmation is precisely what individuals do, who share our values and, above all, have accepted personal risks or even persecution for these values. So, they confirm that our values continue to

21 There is a dogmatic dispute regarding the question of what kind of connection is required between the act of persecution and the reason for persecution. According to the motivation-theory, it depends on whether the persecutor is guided by the motive to combat the "race", religion, political opinion, etc. of the victims. According to the final-theory, it depends on whether a measure actually leads to an impairment of religion or political opinion etc. Cf. Tiedemann (2018c), p. 50.

22 This idea is no longer completely remote from positive law. It finds expression in very complicated and often almost indistinguishable protection statūs, which should somehow be of minor importance. This lesser rank is among others expressed by the fact that the persons concerned are not called 'refugees' in the legal sense, but either bear indistinct terms such as 'beneficiary of subsidiary protection' or have no designation whatsoever. 
be worth identifying. This gives rise to the impulse to provide protection to those who share our values and are persecuted even if the nature and intensity of the persecution have not yet reached the level of human rights violations. This impulse has a moral quality. For we would, so to speak, perceive ourselves as traitors to our own ideals and disqualify ourselves in terms of morality, if we were indifferent to like-minded fellow humans being persecuted. Even the persecuted would morally disqualify us if we ignored their request for protection.

However, the moral relevance of solidarity with like-minded people has another side as well. It does not provide a refugee-ethical reason for the protection of people who are persecuted for a political belief that we do not share, or that is at odds with our own political beliefs (contrary: Funke 2017, p. 538). There is therefore not only a sociological explanation, but also an ethical justification for why Belgian separatists feel obliged to protect the leader of the Catalan separatists, while the advocates of Spanish state unity would see no reason to grant asylum in this case. ${ }^{23}$ Convinced Democrats and defenders of the rule of law feel a solidarity duty to protect Edward Snowden, but they do not consider the protection of Iranian monarchists as morally relevant. ${ }^{24}$

\subsection{The Relevance of Justice-Goods}

It is well known that poverty theory differentiates between absolute and relative poverty (Vaskovics 1995). Absolute poverty occurs when there is a lack of means of elementary gratification that leads to a physical and psychological threat to a person's survival. Relative poverty, on the other hand, occurs when the socioeconomic situation of a person is so low compared to the average standard of living of the population to which he is affiliated that it allows for the satisfaction of the biological-physiological necessities of life, but not or only to a limited extent for the satisfaction of culture and social life. It is obvious that people in absolute poverty lack all or many HR-goods. Therefore, they should be considered worthy of protection. However, these people often lack the necessary resources to finance an escape to potential host-countries. That is why they hardly appear in our lives as refugees (Pogge 2002, 112 et pass.; Gnüchtel 2016). By definition, relatively poor people do not live in conditions that can be described as inhumane, because the means for training and maintaining personhood are available to them. They have good reasons to improve their living conditions even by making great efforts. Therefore, they can be motivated to mobilize their last resources to seek their fortune elsewhere. They then appear as so-called economic refugees.

The refugee ethical relevance of the protection of people of this type cannot be justified by the deprivation of HR-goods and not from the point of view of solidarity. Basically, relative poverty is not a refugee-ethically relevant reason. We do not have to make it our matter to help other people achieve better living and prosperity. This is only the case if we belong to the same community of solidarity. This is not usually the case for people who do not belong to the same political or religious community.

Things are different, however, when the precarious economic situation, which people seek to escape from, is the result of a harmful act, committed by us. In that case, the request for protection turns out to be a demand for compensation for the damage, whereupon

23 Under the leadership of Regional President Carles Puigdemont, the Catalan Regional Parliament passed a Declaration of Independence on 27 October 2017. Consequently, Spanish law-courts issued an arrest warrant for Carles Puigdemont, who escaped to Belgium. (See also https: //de.wikipedia.org/wiki/Carles_Puigdemont). In the case of his return he would be threatened with imprisonment in a Spanish prison. According to the HUDOC database of the European Court of Human Rights, there has been no single case against Spain over the last 10 years involving human rights abusive placement in Spanish prisons. It can, therefore, be assumed that Mr. Puigdemont in the case of his return is only threatened by discrimination with regard to his freedom of movement, but not with violations of his human rights. That is why the question of whether he should be granted asylum depends solely on whether or not one can identify with his political position.

24 However, monarchists in Iran are threatened with treatment contrary to human rights, and for that reason alone their protection is morally relevant. In the case of Edward Snowden, it is about the fact that he made public illegal state practices of the American secret service, NSA, National Security Agency, and thus opened the opportunity to act against administrative or political abuse of power (see https://de.wikipedia.org/wiki/Edward_ Snowden). Snowden received asylum in Russia. If he returns to the US, he faces a long prison sentence. Whether US prisons meet human rights standards is not undisputed—see Amnesty International Report 2017/2018, London: AI 2018, p. 387. 
the injured party has a right according to the second rule of deontological ethics. Relative poverty can only be considered as compensable damage if it is not based on wrong decisions which the concerned themselves are responsible for, or on social, political, or environmental conditions that are not caused by those who are called for compensation. Rather, it must be damage that is causally linked to some kind of unfair behavior by the persons or states who are considered responsible for compensation. I come back to this problem below.

\section{Duties toward Refugees inside the Country}

This and the following two sections deal with the question of the conditions under which the host state in question has specific moral obligations towards persons who, in the light of the foregoing considerations, are to be considered as deserving protection. It will be useful to distinguish between asylum seekers who are already in the territory of the host state and those outside the territory. This section is about the former group. These are people who have either entered the country legally (for example with a tourist visa) or illegally and are now seeking protection.

\subsection{Refugee Status in a Moral Sense}

The positive refugee law in Germany knows not only one, but numerous graduated protection statūs. From a refugee-ethical perspective, these distinctions do not matter. The asylum-related protection status, which alone can be dealt with in a treatise on refugee ethics, is only one. It basically includes two aspects. On the one hand, it includes a right of residence, so that the holders of the protection status cannot be forced to leave the host country and return to the living conditions from which they have fled. On the other hand, the protection status includes the enabling of living conditions in the host state that meet the requirements of fundamental human rights. Only then the flight to the host state can be considered as a real alternative to life in the homeland. Whether and to what extent the host state is obliged to further integrate refugees into the host society for moral reasons is not to be discussed in this essay.

The protection status in the sense of this essay implies that its refusal entails the duty of departure of the respective persons, which can be enforced if necessary, with the means of administrative coercion (deportation). The rule is that a foreigner can normally only be deported or returned to the state of which he is a national. This is usually the country of origin from which he fled. Unlike the positive legal situation, therefore, the moral burden of responsibility is concentrated solely on the choice between granting and not granting protection status. I will limit the discussion to the case that the worthiness of protection is based on a lack of HR-goods in the country of origin. The same applies to the granting of asylum from solidarity. I will return to the case of granting asylum resulting from previous unfair treatment in the next section.

\subsection{Conclusions from the Action-Theory}

The moral assessment of a refusal of the protection status for persons who are worthy of protection depends crucially on whether this refusal must be interpreted as an omission of assistance or whether it is rather an active injury. In the former case, this would be morally relevant only if there is a need to provide help. This requires a special guarantor position, which is normally difficult to justify with regard to refugees from other states. If, on the other hand, it is an active injury, then, as has been clarified above in Section 2, there is a violation of the deontological ban of harming.

Whether the act of refusing protection status to persons in need of protection is to be interpreted as an omission of assistance or as active harming depends essentially on the scope of the underlying concept of action. In the German philosophical and legal theory of action, it was above all G. W. F. Hegel, who shaped the modern concept of action sustainably (Derbolav 1974; Quante 1993). For the Anglo-Saxon area, the theory of action of Jeremy Bentham is to be referenced, which has great similarities with Hegel's conception (Hacker 1976). According to Hegel, an action is an expression of the subjective will of the 
agent. This approach is based on the idea of the free subject whose subjective will must be the yardstick of the attribution of moral responsibility Hegel [1821] $(1955, \S \S 113,114)$.

The first element of action is, according to Hegel, the deed (Hegel [1821] 1955, § 115). A deed is any active behavior of a person (agent) through which world affairs are influenced. In order to be able to qualify a deed as an action, it is necessary that the agent recognizes the change in the world as caused by the deed and, therefore, as their own (Hegel [1821] $1955, \S 114)$. This approach prohibits attributing those consequences of a deed to the agent that is beyond his control. This includes all random and unpredictable consequences. So, according to Hegel, only those consequences can be assigned to a certain agent, which was expected by him at the moment when he decided to act.

Initially, all the consequences that lay in the intention (Absicht) of the agent when he is committing the act are captured by his will. The intention refers to the consequences that the agent wants to realize through the action (Hegel [1821] 1955, § 114). An intention does not exist if the respective person wants to realize no consequences at all with the behavior, with which he influences world affairs. In this case, the act cannot be described as an action. An intention directed to anything is thus constitutive for the existence of an action.

For Hegel, however, not only those consequences of a deed are elements of the action which the agent has included in his intention, but also those that he knew to be committed by his action without intending them. These consequences are captured by what Hegel calls premeditation (Vorsatz) (Hegel [1821] 1955, § 117). They are not intended but accepted by the agent in order to achieve the goal of the action. In that regard, they are covered by his will and, therefore, attributable to him.

In his theory of action, Hegel did not consider and discuss those consequences of an action which we usually attribute to the acting person, but which are neither embraced by the intention nor by the premeditation. In these cases, we speak of negligence. ${ }^{25}$ The problem of negligence is the attribution of consequences that are not covered by the will of the agent. The moral responsibility for negligent acts is based not just on the will that the agent has taken, but on the omission of a careful examination of the expected consequences of the action. Karl Larenz has proposed the connection between negligence and will in the fact that the omission of due care in the consideration of the consequences to be expected is itself based on an act of will, namely, on the will of the agent not to exercise careful considerations (Larenz [1927] 2017, p. 393). In this respect, the essential link between will and action is established, and even the negligent act can be understood as an "expression of the will" (Hegel [1821] 1955, § 113).

Now we can come back to refugee ethics. The denial of protection status is determined by the intention to end the unwanted stay of a foreigner and to organize his return home. The premeditation goes far beyond that. This includes all consequences whose occurrence lies in the knowledge of the competent authorities. The action also covers all consequences of which the authorities are unaware because of the omission of due care (negligence). Therefore, if the authorities know or negligently do not know that the person will be killed in the event of his return to his home country, then the action, which appears superficially as a mere termination of residence, can be described as an act of homicide. If the person is threatened with torture, the deportation can in such a case be described as torture. When forced marriage threatens, deportation is the act of forced marriage. In short, if the acting authorities know or negligently do not know that the person concerned is going into a dehumanizing life situation in the event of returning home, then the refusal of the protection status is an act that violates human rights because it is an act of killing, an act of torture, etc. The refusal of the protection status for persons who are worthy of protection and are staying inside the country thus constitutes an act of injury, and not merely an omission of assistance.

In cases of wars, civil wars, or natural disasters, but also in cases of so-called group persecution (Tiedemann 2018b, p. 46), it is not sufficiently certain that the damage will

25 In (Hegel [1821] 1955, § 116), however, there is a reference to the attribution of the lack of attention, cf. Battistoni (2017), 384. 
actually occur. There is only a certain probability for it. However, incompatible with human rights is not only an act carried out in the definite knowledge of the resulting damage but also an act by which a person is exposed to the serious danger of such damage. Previous endangering behavior establishes namely a corresponding guarantor position. ${ }^{26}$ If, for example, the state exposes a foreigner to the sufficiently concrete risk of death in his home country by denying the protection status, and if this danger finally materializes, then the deportation is to be considered as an act of killing by the state that has failed to protect him. ${ }^{27}$

Hegel's theory of action implies moral responsibility not only for consequences of actions that are intended but also for those that are not intended but foreseeable. This rigidity seems to stand in contrast to the tradition of the so-called doctrine of the double effect, which dates back to Thomas Aquinas (Horn 2006). According to this, there are certain situations in which the agent is responsible only for the consequences that he intended, but not for those that were foreseeable but not intended. The doctrine of the double effect thus serves to justify actions that have predictably bad consequences. Four prerequisites must be met: First, it must be an act that is not already reprehensible in its intentions. The deportation of persons who have no right of residence in the respective state and are, therefore, obliged to leave, it does not appear to be morally reprehensible. Rather, the duty to leave and the deportation serves to produce a morally permissible purpose, namely, the enforcement of state sovereignty over the entry and residence of non-citizens. Secondly, the actor must not intend the foreseeable damage as a means of achieving the actual aim of the act. The damage to the person concerned in the country of destination of deportation, which is foreseeable in the case of deportation, is undoubtedly not a means of achieving the intended purpose. This can be seen from the fact that it is not contradictory or irrational for the authorities and officials involved in the deportation to hope and to wish that the foreseeable damage will not occur. They do not need this damage in order to accomplish the very purpose of the act, namely, the termination of the illegal stay. Third, there must be no way to achieve the intended aim without causing harmful effects. This condition is also met in the case of administrative execution of the obligation to leave the country. It is not possible to end the illegal stay without exposing the person concerned to the damage to be expected. Fourth, the harmful effects must not be disproportionately severe in relation to the desired aim of the action. At least at this point, it turns out that deportation that causes serious damage in the country of destination cannot be justified by the doctrine of the double effect. The aim of the action, namely, the ending of the illegal stay, weighs far less than the expected serious human rights violation in the country of destination. In Thomas Aquinas, the doctrine of the double effect serves the solving of moral dilemmas, such as the problem of defending one's life against an attacker, when the defense is necessarily linked to the death of the aggressor. In the case of ending an illegal stay, there is no comparable moral dilemma. This applies even if the person to be deported is a "potential attacker" or a terrorist offender, for terrorists can be fought and punished without violating human rights. What is possible for terrorists who are citizens of the respective state is also possible for foreign terrorists. Therefore, the doctrine of the double effect is not applicable here. It may remain unclear whether or not this teaching is convincing in the cases for which it is intended. This question does not need to be explored here.

\subsection{Conclusions for the Positive Refugee Law}

In light of the moral-philosophical analysis, the positive international refugee law is partly confirmed and shows partly some deficiencies. The moral considerations confirm

26 This is accepted in judicial doctrine and case law, cf. (BGH 2000). It can, however, also be justified in terms of morality.

27 Concerning the question of when the danger is sufficiently serious, the principle has been developed in German case law that the likelihood of injury must be more than 50 percent in order to justify the worthiness of protection. Cf. critically: Tiedemann (2016b). Berlit denies the present validity of this dogma, cf. Berlit (2017). 
the figure of the refoulement ban but it denies all the restrictions that are accepted in international law.

The oldest provision of the refoulement ban is codified in Article 33 GRC, but it prohibits the expulsion or the forced return in a foreign country only in the case that the refugee is threatened there in his life or freedom and not in any other case of a threatening severe violation of human rights. Furthermore, deportation is only prohibited if the refugee's life or freedom is threatened on account of particular persecution grounds (race, religion, nationality, membership of a particular group, or political opinion). Finally according to Article 33 para 2 GRC a refugee is not protected against forced return "whom there are reasonable grounds for regarding as a danger to the security of the country in which he is, or who, having been convicted by a final judgment of a particularly serious crime, constitutes a danger to the community of that country". All these restrictions of the applicability of the norm are not compatible with the unconditional and absolute validity of human rights. It can only be applied in cases of asylum on reasons of solidarity.

The next step of development was achieved when the UN Convention Against Torture (CAT) came into force (10 December 1984). According to Article 2 CAT, no one may be expelled, returned, or extradited to a state where there are substantial grounds for believing that he would be in danger of being subjected to torture. This provision is without any restriction clause. It meets therefore much better the requirements of the ethical analysis than the GRC does. However, it is only applicable in the case of torture in the narrower sense, whereas the Convention does not provide for a prohibition of refoulement for threatened inhuman or degrading treatment. It is obviously based on the idea that contracting parties (here: of the CAT) are morally free to decide in which cases of human rights violations the refoulement ban should be applied and in which cases it should not.

A third step was done when the European Court of Human Rights (ECtHR) decided that according to the European Convention of Human Rights the refoulement ban has to be applied in cases of inhuman or degrading treatment (ECtHR 1989; Thurin 2009). Since then, however, the Court has never made it clear that what applies to torture and inhuman treatment also applies to all other ("fundamental") human rights. Only in rare cases is it considered a refoulement ban in the case of threatening death (ECtHR 2005), the death penalty (ECtHR 2010), slavery (ECtHR 1999; BVerfG 2020), or a "flagrant denial of a fair trial" (ECtHR 2004). The case law suffers from the fact that the deeper ethical basis of the refoulement ban was never sufficiently clarified. The action-theoretical analysis shows that the refoulement ban cannot be considered as a special regulation besides the right to asylum or as the content of such a very special right. It is rather an integral part of every ("fundamental") human right. ${ }^{28}$ An autonomous right to asylum beside the list of classical human rights is, therefore, redundant if threatening human rights violations are at stake. ${ }^{29}$ Therefore, a special positive right to asylum is only to consider for cases of asylum in the frame of solidarity, where there is no threat of deterioration in HR-goods, but only minor impairments. Considering these arguments we must conclude that human rights law is the primary source of refugee protection, while the special refugee law including Article 33 of the Geneva Refugee Convention "is bound to play a complementary and secondary role" (Chetail 2014, p. 22). Furthermore, it is not sufficient to regard the refoulement ban only in the case of torture as customary international law (Hofmann 1999; Richter 2016, p. 51). Considering the classical human rights as customary international law it follows that even

28 The question what is meant by "fundamental" cannot be clarified in this paper. In any case, those rights must be considered fundamental which, according to Article 4 of the International Covenant on Civil and Political Rights of 19 December 1966 cannot be overridden even in the event of a national emergency.

29 In positive law the right to asylum has a different content compared with the refoulement ban because it includes a right to stay and the access to labor, education, etc. The refoulement ban in contrast guarantees only protection against a forced return to a country, where the refugee is threatened but not a right to stay or access to the institutions of the host society (Hofmann 1999). The right to asylum is this sense refers to the question of integration in the host society that is not the topic of this paper. 
the refoulement ban in the event of every ("fundamental") human rights violation is to be regarded as customary international law.

\subsection{Objections to the Refoulement Ban}

Despite the fact that the refoulement ban is now at least partially recognized as customary international law and individual authors even claim the ius cogens nature of this rule (Allain 2001), the practice of rejection, especially push backs without examination of the individual case, is widespread in the world of states (Amnesty International 2018; Bast et al. 2020, p. 26). In most cases, states simply deny this fact when they are publicly criticized for it. However, there is also an ethical argumentation with which it seems to be possible to justify this practice. The argument goes as follows: It is unacceptable to protect refugees who have imposed themselves through their illegal entry and by doing so deprived the host society of the freedom to decide freely whether and to what extent they want to protect refugees.

This argument follows a pattern known from the moral-philosophical debate about abortion. Judith Javis Thomson, for example, has argued that the embryo, nesting itself in the mother's uterus against her will, makes improper use of her body because the mother has not granted him the right to use her body. The mere fact that the mother made the pregnancy possible by unguarded or poorly-guarded intercourse does not mean that she has granted the embryo a right over her body, like no one who forgets to close his window gives up to the burglar the right to use his apartment. Therefore, according to Thomson, there must be a right to abortion. After all, according to Thomson, we have no responsibilities toward other people unless we have expressly and voluntarily accepted them (Thomson 1971).

Behind Thomson's argument is the view that there are no unconditional human rights, but only obligations that are subject to voluntary takeover. This attitude is incompatible with the idea of human rights as it is displayed in Section 3. Thomson tries to make her argument plausible with the help of a thought experiment ("unconscious violinist"). However, this thought experiment misses the problem, because it describes the situation of forced assistance and does not deal with the question of whether it may be allowed to actively kill others in order to maintain their own autonomy.

\section{Duties toward Refugees Abroad}

This section will cover the moral duties to be performed on protection-worthy people who have left their homeland to seek protection elsewhere, but who are outside (and far away from) the potential host state. For example, what obligations does the potential European host state $S$ have concerning refugees who have left their home country of Eritrea and are now in Ethiopia, Sudan, or Libya, where they are in mortal danger? Do strict prohibition duties play a role in this situation, or does $S$ have any duties to assistance?

Let's assume that $\mathrm{S}$, despite the misery of the refugees, does not develop any activities anywhere in Africa. In order to judge this absence of activity morally appropriate, it must first be clarified how it has to be interpreted in terms of action theory. Two alternative interpretations of this behavior are possible: either it is unintentional inactivity, or it is intentional inactivity. From a moral point of view, "merely doing nothing" is irrelevant because there is no intention. On the other hand, if there is an intention, the behavior becomes morally relevant. Intentional inactivity is called omission. We can say that an omission is a "negative" action. In contrast, "mere doing nothing" cannot be considered as an action. If the situation is described correctly as "merely doing nothing", then, in the case the refugees die everywhere in Africa, it cannot be said that $S$ killed them. In this interpretation, $\mathrm{S}$ does not violate any moral prohibitions. Only if the behavior of $\mathrm{S}$ can be interpreted as a "negative" act or omission, the question raises whether the death of the refugees in Africa can be considered a deliberate or negligent (negative) act of homicide for which $\mathrm{S}$ is responsible. 
The inactivity that $\mathrm{S}$ shows in the face of desperate refugees in the Sudanese desert cannot reasonably be interpreted as a negative action (omission), but only as unintended inactivity. Even if A has awareness of the consequences of its inactivity, it does not pursue any intentions with its inactivity. Therefore, there is no action. The element of an intention (not of premeditations) is constitutive and cannot be removed without the deed or the omission ceased to be an action (positive or negative) (Quante 1993, p. 205). Thus, if there is no action, then the question is not which further consequences the deed or the inactivity covers. Rather, a violation of human rights by $S$ simply does not take place.

If by doing nothing, $\mathrm{S}$ does not violate moral prohibitions, the question arises of whether $\mathrm{S}$ can be blamed for violating its moral duty to render aid. That is the case when there is a duty to provide the necessary help in favor of the refugees in the Sudanese desert. It is only possible to speak of a moral obligation which is (in the meaning of Kant) not a virtue duty but a legal duty if this duty corresponds to a moral right. This is the case only if it is possible to somehow morally "sue" the fulfillment of the duty. The moral grounding of duty and of the corresponding right presupposes that it is possible to establish unequivocally for any given case whether, by whom, and toward whom the obligation has been fulfilled or has been violated. ${ }^{30}$ Regarding the Eritrean refugees in the Sudanese desert, it is not clear that $S$, of all things, has to provide help and not any other country. Even if $S$ is in principle obliged to provide assistance, it is not clear that this is to be done in the face of those people who are currently in a certain place in the Sudanese desert. S could also deploy its resources in other parts of the world, but this means that the people in the Sudanese desert do not have a right toward $S$ to be rescued. Since a sufficiently clear and certain duty to help cannot be defined there cannot be a respective right. Since there is no right, there is no duty.

For Jaako Kuosmanen, however, this indeterminacy is not a sufficient reason for releasing the states of the world from their moral responsibility. According to Kuosmanen it is true that there is no moral duty of every single state individually to help each and every needy refugee everywhere in the world. However, there would be a moral duty to create the necessary global institutions, equipped with the necessary material and personal resources, to provide the necessary protection for all those who are in morally relevant need (Kuosmanen 2013). ${ }^{31}$

However, this argument is not convincing because there cannot be any obligation with regard to a specific state to create supra-state institutions or international institutions. For duties cannot go beyond the ability to fulfill them (ultra posse nemo obligatur). A single state cannot create global institutions because this requires cooperation with at least some other nations. No single state is capable of creating global institutions if nobody cooperates. Whether the others participate is beyond the control of the individual state. What is beyond control cannot be the subject of duty. Social institutions in general and global institutions in particular only emerge at rare historical moments, often following a man-made disaster (war, banking crash, economic crisis) within a very small temporal window of opportunity.

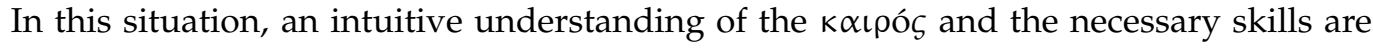
needed to send out relevant impulses to the international community, to take the initiative and make convincing proposals. However, there cannot be any moral obligation to have this intuition and skill. Only when the institution-building process is in place can there be a moral duty not to refuse this process, not to weaken the new institution, and to do its utmost to promote its effectiveness. So long as there is no global refugee protection institution, there is no direct or indirect obligation on the part of states to provide assistance to refugees outside their area of control.

Not only the vagueness of possible duties to assistance but also the lack of a guarantor position opposes the ethical foundation of such duties towards refugees abroad. The

30 Wildt (2007) points to a special kind of ("mild") duties, which differs from other duties by the fact that they do not correspond to rights, although they are sufficient determined and can be made a matter of sanction. However, duties of this kind do not play a role here.

31 For the discussion of burden sharing see also Miller (2016), p. 171. 
deontological moral theory always demands the existence of a special guarantor position for such obligations. This is missing here. Therefore, all that ultimately remains is a call to a general humanitarian attitude (virtue) of the states in the hope that at least they will do something in favor of those in need (Tugendhat 1995). By doing so, states do not fulfill moral duties nor meet their moral rights. Rather they show activities that are considered praiseworthy and desirable. This is what in ethical terminology is called supererogatorical.

The situation is different, however, when a given potential host state has a guarantor position with regard to specific or individually identifiable refugees. Such special relationships can arise from a policy toward the refugees' country of origin, which results in specifically understandable damage to the refugees and, therefore, a duty to compensation. ${ }^{32}$ However, there are no special obligations of this nature vis-à-vis all refugees from the global South or against all those who want to escape (absolute or relative) poverty. Damage from the colonial period, for example, does not lead to a duty to compensate for states that have not even appeared as a colonial power in the area of origin of the respective protection seeker. Even to the former colonial states, a sufficient causal link between the damage at that time and today's claim for compensation must be proven. Those seeking protection cannot rely indefinitely on the damage that was caused centuries ago.

Thomas Pogge (Pogge 2008, p. 141) like Iris Marion Young (Young 2006) or Henning Hahn (Hahn 2014) argue that a claim for compensation also results from the damage caused by the current structure of the global economic order. This order contributes significantly to poverty, corruption, and tyranny in many countries of the global South. According to Pogge, every person who contributes to the maintenance of this order (for example, through tax payment, consumption, political participation, and electoral behavior) contributes to this damage as well (Pogge 2008, p. 72). From this entanglement into unjust structures arises, according to Pogge, no moral duty to active world improvement, but the negative moral duty to refrain from structural harming. Anyone who violates this negative moral duty takes part in the persisting injury and is, therefore, obliged to compensate for the damage.

However, to be no longer involved in the damaging outcomes of the system of global economic order requires more than a mere omission. People can escape their responsibilities, as it is understood by Pogge, only when they stop paying taxes, which is only possible if they stop generating taxable income or taxable consumption. ${ }^{33}$ This cannot be done without abandoning civic existence. Such behavior goes beyond mere omission. Even if one waives the participation in political elections, because, for example, all parties standing for election either support the unfair global economic order or are political gamblers, this tends to benefit only the radical parties and does nothing to abolish unjust structures. Structural injustice is inescapable for a single individual. In several passages of his book, Pogge points out that his moral appeals are directed to the "significant and continuing participants" of the system, or "at least" to the "more privileged and influential citizens," who only "in some cases" should reform the system or protect its victims (Pogge 2008, pp. 140, 178). This does not speak for strict omission duties, but rather for positive, but only "imperfect" obligations to improve the world, which can only be met by those who have unusually much more influence and power.

Furthermore, it raises the question of whether the reception of refugees would be the appropriate compensation for damage caused by the structural injustice of the global economic order. Some academics answer this question in the affirmative (Hoesch 2016, p. 21; Schlothfeldt 2002, 93 et pass; Bader 2002, 143 et pass.). According to Pogge, this order

32 Such compensation obligations may arise, for example, from the free trade agreements that the EU is currently negotiating with five African groups of states or has already concluded. These agreements stipulate that raw materials as well as semi-finished and finished products can be exported duty-free to the respective contracting states. In fact, this means that, for example, by exporting heavily subsidized wheat to African countries, Europe brings the manioc or sorghum peasants there to ruin because their prices are significantly higher than those of European imports because of higher production costs. If these farmers lose their livelihood and therefore set out to find their livelihood in Europe, then they have a right of entry, residence, and work permit from the point of view of the deontological compensation duty. See for this problem: Pfaff and Piper (2016); Abiola-Costello (2016); Groth and Kneifel (2007).

33 That is the tragedy of conscientious tax refusal, cf. Tiedemann (1991) 
is characterized above all by the international resource privilege and the international borrowing privilege. The former consists of the fact that every de facto ruler in the poor states has the legal power to transfer global ownership rights on the country's resources, which has the consequence of being able to enrich themselves at the expense of the population of their country (Pogge 2008, p. 119). The international borrowing privilege allows the rulers in poor countries to borrow on behalf and at the expense of the population and thus, in order to preserve their tyrannical and exploitative system, impose legal payment obligations on the whole country, which will continue to exist even in the case that the tyrannical rule can be terminated (Pogge 2008, p. 120). The damage caused by these two privileges to the poor countries, however, cannot be compensated by the reception of refugees. If one assumes, with Pogge, that every consumer or taxpayer in the rich countries actually contributes to the damage by his or her behavior, then the reception of refugees from the affected poor countries would lead to the fact that these people would become additional consumers and taxpayers. They would, therefore, also contribute to the unjust conditions under which they themselves suffered before. The damage would not be eliminated, but only the number of perpetrators increased. This shows that systemic injustices and the resulting damage cannot be compensated by receiving refugees. Pogge himself does not suggest this kind of compensation but calls for the reform of the global economic order. Of course, such a reform would result in ceasing numerous motives for flight and emigration.

The issue of climate refugees is often considered as a matter of compensation (Penz 2010; Risse 2009; Baatz 2017; Ott and Riemann 2018, p. 31). However, there are many empirical obstacles that make it difficult to determine who exactly and for what exactly the damage can be considered responsible (Wyman 2013, p. 193).

So, it remains that assistance for refugees outside the territory of the host state is not an obligation, but only addresses the virtue of humanity. It is incompatible with this virtue, however, to respond indifferently to the misery of refugees around the world. Rather, the decent state, because of its humanitarian attitude ("virtue"), is required to take serious and careful consideration of the extent to which it should bring refugees to its territory and protect them through resettlement programs. All aspects that are appropriate must be taken into account. At the same time, the consideration of all inappropriate aspects must be avoided.

Some authors argue that consideration of the extent of humanitarian aid to refugees should not only take into account the state's own objective capacity, but also the criterion of fair burden-sharing among all states of the international community. The consideration of this criterion should apply regardless of whether such a burden-sharing actually takes place (Cohen 1981, p. 73; Pogge 2008, 296 fn 246). Accordingly, it is appropriate to determine, by means of a fictitious calculation, how many refugees each individual state would have to take if a fair burden-sharing took place. On the basis of such a scheme, the state has to accept only a number of refugees according to its own quota. However, such a fictitious burden-sharing scheme is not appropriate. Decisive for the question of the maximum limit up to which refugees should be received is not fictive numbers games, but only the objective capacity (Kuosmanen 2012).

The proper consideration of the kind and number of refugees to be received does not allow for a mathematical conclusion on the number of refugees who actually have to be admitted. In that regard, there is rather a political margin within which various choices are possible, none of which is morally reprehensible. Therefore, there is no moral obligation to a "correct calculation". From a moral point of view, it remains rather in the appeal to the humanitarian self-understanding of the respective state and its citizenry. The political decision, however, must be based on a realistic assessment of objective performance, in the clear awareness of what we can and what we want. This includes a clear awareness of what we can do but do not want to do. An information policy that distorts the perception of the objective capacity is morally reprehensible because it is manipulative and leads to collective self-deception. 


\section{The Border between "Inside" and "Outside"}

The moral obligations to refugees who are already inside the host country differ therefore very fundamentally from what can be morally demanded by refugees abroad. The former may appeal to moral rights, the latter may appeal only to the humanitarian sentiments ("virtues") of possible host states and their citizenry. Peter Singer has criticized this distinction as arbitrary: Those who could afford the trip, would be protected, the others would be left to themselves (Singer 2015). Nevertheless, this asylum paradox is well-founded. The apparently offensive contingency is due to the nature of guarantor duties. A doctor has a guarantor position only toward the patients who have been accidentally admitted to his hospital and not to all people who suffer from the same disease. Parents owe their care only to the children, who happen to be their own, and not to all those in need of care. So, a certain kind of arbitrariness seems to be inherent to the conception of a guarantor position. However, in fact, the arbitrariness appears only if we focus on the respective need and not on the obligation to support those in need. The obligation is not based on arbitrariness but well-founded in the different human relationships and in the crucial difference between acting and non-acting.

The big moral difference between "inside" and "outside" the host country makes the question relevant to where exactly the boundary between them runs. So far, I have just distinguished between a stay of refugees inside and outside the territory of the host state. This distinction is far too blurred. Rather, it is crucial whether the refugees are in a situation, for which a particular state can be identified who can perform certain acts on certain vulnerable individuals.

These conditions are met not only for refugees already inside the country but also for those who are right on the border and are seeking asylum there. Simply by expressing a request for protection at the border, the refugee put the state in a situation in which it is no longer able to do simply nothing. Rather, it is confronted with only two alternative options: either it hinders the refugee to cross the border or it refrains from doing so. Regardless of how it decides, this decision is, in any case, steered by an intention and, therefore, a positive or a negative kind of action that is inescapably linked to the responsibility for any consequences that the state authorities know or negligently not know. Nor can the State escape that responsibility by taking measures that make it impossible for the refugees to make a verbal or written asylum application to an official. For such measures already presuppose that the state knows about the existence of refugees whose formal application they want to prevent. This knowledge compels a decision and thus an action.

The moral responsibility of the state toward refugees on its border generates the duty to refrain from measures against entry if otherwise the prohibition of a violation of human, solidarity, or compensation rights would be violated (Keil 2015, 179). If entry is nonetheless denied, then this constitutes an immoral action of damage.

One hesitates, however, to agree with these considerations in the event that there are millions of people at the border who we know are all threatened in HR-goods and, therefore, worthy of protection. Julian Nida-Rümelin has applied the Golden Rule to the refugee issue for this situation and formulated: "Do not demand anything that you do not accept in your close social area, and practice in the close social area what you expect from migration policy." (Nida-Rümelin 2017a, p. 154) In theory, scenarios are conceivable in which a morally correct behavior could lead to the downfall of our state. With 65 million vulnerable refugees at the German borders, that would probably be the case. However, in such a situation we would face the choice between two options: either to protect our kind of living, necessarily by force of violence and in a morally reprehensible way or the option to remain morally and to perish. Socrates formulated the ethical point of view in such a situation: it is anyway better to suffer evil than to do it (Platon 1966a, Gorgias 469c). In any case, in front of the forum of history, we would have to be accused of stupidity, because we remained passive when it still would have been possible to prevent huge flight movements by doing something against impending wars, climate disasters, and economic misery in the world. 
The real situation in Europe, the Americas, or Australia, however, is not characterized by such scenarios. ${ }^{34}$ Rather, the real problem is that we can know or can presume that only some of the people at our borders are worthy of protection, and another probably larger part is not. However, it is not possible to determine prima facie, whether a single individual belongs to one group or to the other. ${ }^{35}$ However, this initial ignorance does not follow that the authorities which have to meet the moral obligations would not be able to identify those who are worthy of protection, and those who are not. The duty not to harm those who are worthy of protection covers the duty to make any effort in order to identify them. It is recognized that the person wishing to assert a right bears the burden of explanation and proof. However, from the state authorities, it is required in any case that they take note of and examine the presented statements and evidence. The state must not play artificially "stupid" but must give those affected the opportunity to make the moral obligation plausible. It must, therefore, establish a sufficient and fair procedure in order to determine refugee status. From a moral-philosophical point of view, there is no objection to all asylum-seekers being first admitted to a reception center close to the border or on an island offshore, which they are not allowed to leave in direction to the host country until their right to protection has been recognized. There is also no moral objection against the practice of deporting those whose procedure led to a negative result directly to their home country. The problem with such reception facilities, however, is that the state that runs such facilities takes responsibility for decent living conditions in the facilities, even if certain restrictions may be reasonable for a manageable transitional period. This duty arises from a guarantor position that the state enters by running reception facilities which the asylum seekers cannot escape from and in which they cannot provide sufficiently for their own lives.

However, there are factual limits of what the state can do in order to identify those who are worthy of protection. The efforts connected with the asylum recognition procedure cannot be endless. From a weakly organized, resource-poor, and even more fragile state, less can be demanded in this respect than by well-functioning, stable, and prosperous states (Funke 2017, p. 541). However, at least theoretically it is conceivable that even strong states will someday reach the limits of administrative control. However, that would not justify refusing entry to people in need of protection at the border simply because the state does not want or cannot commit any further identification effort. In such a situation, there remains only one morally correct solution, namely, to open the borders and let everyone enter who wants to enter. Such an approach would permanently eliminate the function of the state border altogether and ultimately result in the waiver of territorial integrity. That would be politically undesirable from the national perspective, but no moral misconduct would occur. States do not have the moral right to defend their territorial integrity by means of human rights violations. ${ }^{36}$

A special consideration deserves the situation of refugees who are on the way to the borders of a possible host state at sea (Papastravridis 2020). What rights do they have toward the possible host state or any state? - We have to distinguish between the stay in the territorial sea (12 miles zone) and they stay on the high seas. For both areas, first of all, no state has the right to prevent refugees from continuing their sea voyage or to push them back to areas where they are not safe. This is true on the high seas already because of

34 At the end of 2016, there were approximately 22.5 million registered refugees and 2.5 million asylum seekers worldwide. 720,000 asylum applications were registered in Germany, cf. IOM (2018).

35 The protection rate of the Federal Office of Immigration and Refugees (BAMF) was 62.4\% in 2016 and 38,3\% in 2019. Even taking into account that lawsuits were filed against many negative decisions, a considerable proportion of unsuccessful asylum applications remains-cf. BAMF (2020), p. 52 .

36 It follows from these considerations that Chancellor Merkel's decision of 14 September 2015 not to close the borders and to allow unchecked entry of all people who were at the Hungarian and Austrian borders was morally justified. Ms. Merkel herself never intended to make the opening of the borders permanent. It was all about a temporary loss of control that had to be accepted to avoid a current looming violation of human rights. Critical to this political decision from a legal perspective, however Di Di Fabio (2016). Cf. also the reply of Bast and Moeller (2016). 
the freedom of navigation there. ${ }^{37}$ In the territorial sea, the coastal state exercises its full sovereignty. Here, however, it is not allowed to prevent refugees from reaching a border crossing point where they can file an asylum application.

However, if the refugees, from whom we hear terrible news from the Mediterranean almost every day, find themselves in distress at sea, threatened to drown, and, therefore, depend on rescue measures, they cannot invoke any refugee-ethical duties of a state or private individuals to rescue them. For it lacks an appropriate guarantor position. There is, however, a duty to rescue shipwrecked from distress at sea. However, this is not a moral obligation based on a corresponding guarantor position, but a duty of international law recognized by positive law. From a moral point of view, it can be understood as a solidarity duty arising from the fact that ships that meet each other on the high seas build a solidarity community. According to this, captains are required to render assistance to any person found at sea in danger of being lost, as long as this is possible without serious danger to the ship, its crew, or passengers. ${ }^{38}$ The persons to be rescued are in any case to be taken on board and taken to a safe place. However, there is no obligation to go to the sea for the purpose of saving people in distress at sea. Furthermore, the obligation to rescue people in distress at sea does not justify claims beyond the immediate lifesaving, such as a permanent residence or the granting of asylum (Wissenschaftlicher Dienst 2016, p. 8). Those who decided to become involved in SAR (search and rescue) operations on sea perform acts of benevolence that are to be estimated as morally valuable (supererogatorical acts) but not morally required. From the positive value of their acting follows, however, that it is immoral to punish them for what they do (Mann 2020; Bast et al. 2020, p. 124).

From the view of refugee ethics, sea rescue as such is not a matter of a specific moral duty. However, the fact that rescued people aboard a ship are under the de facto power of the captain of this ship is what counts in the frame of refugee ethics. If the captain decides to take them to the port of a country where they are subjected to human rights violations, then the captain themselves violates human rights. He or she is to consider as a performer of the acts of maltreatment the refugees have to suffer there. To avoid that, all they can do is to take the refugees to a harbor where they are safe. ${ }^{39}$

As this case shows, the boundary between "inside" and "outside" shifts with the widening of the factual power of both individuals and states. This refugee-ethical insight will become more and more important in the future. The European Union is trying to enable countries deep in Africa to prevent effectively refugees from passing to Europe. The EU supplies for that reason effective technical and administrative means as well as arms. African despots are rewarded with equipment for the police and the army if they promise to lock refugees up in internment camps or prevent them from traveling through. So, the EU builds an efficient border regime far away from the actual legal border. This extends Europe's responsibility to those areas outside its own territory which, as a result of this policy, come under European control. So, the death of refugees who die because they are hindered to cross the border of African states or are hindered to leave an African State in the direction of Europe becomes an act of killing, committed by the European Union and its member states (Jakob and Schlindwein 2017; Koch et al. 2018).

Funding: This research received no external funding.

Institutional Review Board Statement: Not applicable.

Informed Consent Statement: Not applicable.

Data Availability Statement: Not applicable.

37 Article 58 I and Article. 87 I UN-Convention on the Law of the Sea (UNCLOS)—UNTS, vol. 1833, p. 3.

38 Article. 98 I UNCLOS; the principle is recognized as customary international law, cf. Wissenschaftlicher Wissenschaftlicher Dienst (2016).

39 This view corresponds more or less to the legal position as stated by the ECtHR (2012). The US Supreme US Supreme Court (1993) defends a different opinion. 
Acknowledgments: The author thanks James C. Simeon, York University Toronto for the review of the text in terms of grammatical, stylistic and orthographic mistakes. All remaining errors are the author's sole responsibility.

Conflicts of Interest: The author declares no conflict of interest.

\section{References}

Abiola-Costello, Hafsat. 2016. Europa Erzeugt die Flüchtlinge Selbst. Zeit.de of 1/8/2016. Available online: http:/ /www.zeit.de/ kultur /2016-07/ westafrika-freihandelsabkommen-eu-fluechtlinge-hafsat-abiola/ (accessed on 3 November 2020).

Allain, Jean. 2001. The jus cogens Nature of non-refoulement. International Journal of Refugee Law 13: 533-58. [CrossRef]

Amnesty International. 2018. The States of the World's Human Rights. Report 2017/18. London: Amnesty International.

Anderson, Bridget, Nandita Sharma, and Cynthia Wright. 2009. Why no Borders? Refuge 26: 5-18. [CrossRef]

Anscombe, Elisabeth. 1958. Modern Moral Philosophy. Philosophy 33: 1-19. [CrossRef]

Baatz, Christian. 2017. Compensating the Victims of Climate Change. Doctorial dissertation, University of Greifswald, Greifswald, Germany.

Bader, Veit. 2002. Praktische Philosophie und Zulassung von Flüchtlingen und Migranten. In Was schulden wir Flüchtlingen und Migranten? Grundlagen einer gerechten Zuwanderungspolitik. Edited by Alfredo Märker and Stephan Schlothfeldt. Wiesbaden: SpringerVS, pp. 143-67. [CrossRef]

Bundesamt für Migration und Flüchtlinge (BAMF). 2020. Jahresgerichtsstatistik. Available online: https://www.bamf.de/SharedDocs / Anlagen/DE/Statistik/BundesamtinZahlen/bundesamt-in-zahlen-2019.pdf?_blob=publicationFile\&v=3 (accessed on 3 November 2020).

Bast, Jürgen, and Christoph Moeller. 2016. Dem Freistaat zu gefallen: Über Udo Di Fabios Gutachten zur staatsrechtlichen Beurteilung der Flüchtlingskrise, VerfBlog 2016/1/16. Available online: verfassungsblog.de/dem-freistaat-zum-gefallen-ueber-udo-difabios-gutachten-zur-staatsrechtlichenbeurteilung-der-fluechtlingskrise/ (accessed on 3 November 2020).

Bast, Jürgen, Frederik von Harbou, and Jana Wessels. 2020. Human Rights Challenges To Euroean Migration Policy (REMAP), 1st ed. Available online: https:/ / www.migrationundmenschenrechte.de/de/topic/541.remap.html (accessed on 3 November 2020).

Battistoni, Giulia. 2017. Die Möglichkeit des Wissens als Grundlage der Zurechnung. RphZ 2017: 380-95. [CrossRef]

Bayertz, Kurt. 2014. Warum überhaupt Moralisch Sein? 2nd ed. München: C.-H. Beck.

Bedarff, Hildegard, and Cord Jakobeit. 2017. Klimawandel, Migration und Vertreibung. Die unterschätzte Katastrophe. Hamburg: Greenpeace, Available online: https:/ / www.greenpeace.de/sites/www.greenpeace.de/files/publications/20170524-greenpeacestudie-klimawandel-migration-deutsch.pdf (accessed on 3 November 2020).

Berlit, Uwe. 2017. Die Bestimmung der 'Gefahrendichte' im Rahmen der Prüfung der Anerkennung als Flüchtling oder subsidiär Schutzberechtigter. ZAR 37: 110-20.

Bundesgerichtshof (Federal Supreme Court) (BGH). 2000. judgement of 20/06/2000—4 StR 162/00. Available online: https://juris. bundesgerichtshof.de (accessed on 3 November 2020).

Brezger, Jan. 2016. So viele wie nötig und möglich! Die Pflicht zur Aufnahme von Flüchtlingen und die Spielräume politischer Machbarkeit. In Welche und wie viele Flüchtlinge sollen wir aufnehmen? Philosophische Essays. Edited by Thomas Grundmann and Achim Stephan. Stuttgart: Reclam, pp. 57-69.

Broad, Charlie Dunbar. 2001. Five Types of Ethical Theory. London: Roudledge, p. 206. First published 1930.

Bundesverfassungsgericht (BVerfG). 2020. Decision of 25/09/2020—2 BvR 854/20. Available online: https:/ / www.bundesverfassungsgericht. de/SharedDocs/Entscheidungen/DE/2020/09/rk20200925_2bvr085420.html (accessed on 3 November 2020).

Carens, Joseph H. 1987. Aliens and Citizens. The Case for Open Borders. The Review of Politics 49: 251-73. [CrossRef]

Carens, Joseph H. 2013. Ethics of Immigration. Oxford: OUP, p. 225.

Cassee, Andreas. 2016. Globale Bewegungsfreiheit. Ein philosophisches Plädoyer für offene Grenzen. Berlin: Suhrkamp.

Chetail, Vincent. 2014. Are Refugee Rights Human Rights? An Unortodox Questioning of the Relations between Refugee Law and Human Rights Law. In Human Rights and Immigration. Edited by Ruth Rubio-Marín. Oxford: Oxford Scholarship Online, pp. 19-69. [CrossRef]

Cohen, Jonathan L. 1981. Who is Starving Whom? Theoria 47: 65-81. [CrossRef]

Collins-Chobanian, Shari, Eric Commerford, and Chris Kerlin. 2010. Twenty Million Environmental Refugees and Counting: A Call for Recognition or a New Convention. Environmental Ethics 32: 149-63. [CrossRef]

de Oliveira, Pauline Endres. 2016. Legaler Zugang zu internationalem Schutz. KJ 49: 167-79. [CrossRef]

Derbolav, Josef. 1974. Handeln, Handlung, Tat, Tätigkeit. In Historisches Wörterbuch der Philosophie. Edited by Joachim Ritter. Darmstadt: WBG, vol. 3, column 992 et pass.

Derpmann, Simon. 2013. Gründe der Solidarität. Münster: Mentis.

Di Fabio, Udo. 2016. Migrationskrise als föderales Verfassungsproblem. Available online: http://www.bayern.de/wpcontent/ uploads/2016/01/Gutachten_Bay_DiFabio_formatiert.pdf (accessed on 3 November 2020).

European Court of Human Rights (ECtHR). 1989. Judgement of 07/07/1989-1/1989/161/217_“Soering v. UK”. Available online: https:/ / hudoc.echr.coe.int (accessed on 3 November 2020).

European Court of Human Rights (ECtHR). 1999. Judgement of 19/01/1999—42367/98—“Ould Barar v. Sweden”. Available online: https:/ / hudoc.echr.coe.int (accessed on 3 November 2020). 
European Court of Human Rights (ECtHR). 2004. Judgement of 22/06/2004-17341/03—“F. v. UK”. Available online: https: // hudoc.echr.coe.int (accessed on 3 November 2020).

European Court of Human Rights (ECtHR). 2005. Judgement of 08/11/2005-13284/04_“Bader et al. v. Sweden”. Available online: https://hudoc.echr.coe.int (accessed on 3 November 2020).

European Court of Human Rights (ECtHR). 2010. Judgement of 02/03/2010—61498/08_“Al-Saadoon et al. v. UK”. Available online: https:/ / hudoc.echr.coe.int (accessed on 3 November 2020).

European Court of Human Rights (ECtHR). 2012. Judgment of 23/02/2012-27765/09_“Hirsi Jamaa v. Italy”. Available online: https:/ / hudoc.echr.coe.int (accessed on 3 November 2020).

Festinger, Leon. 1957. A Theory of Cognitive Dissonance. Stanford: SUP.

Funke, Andreas. 2017. Das Flüchtlingsrecht zwischen Menschenrecht, Hilfspflicht und Verantwortung. JZ 72: 533-37. [CrossRef]

Gnüchtel, Ralf. 2016. Das Potential der Armutsmigration aus den afrikanischen Staaten südlich der Sahara. ZAR 36: $172-77$.

Goffman, Erving. 1961. Asylums. Essays on the Social Situation of Mental Patients and Other Inmates. New York: Anchor Books.

Gosepath, Stefan. 2003. Verteidigung egalitärer Gerechtigkeit. DZPhil 51: 275-97. [CrossRef]

Groth, Annette, and Theo Kneifel. 2007. Europa plündert Afrika. Der EU-Freihandel und die EPAs. Hamburg: VSA.

Hacker, Peter M. S. 1976. Benthams Theory of Action and Intention. ARSP 62: 89-110.

Hahn, Henning. 2014. Globale Gerechtigkeit. Das Prinzip kosmopolitischer Verantwortung. In Gerechtigkeit. Vom Wert der Verhältnismäßigkeit. Edited by Clemens Sedlak. Darmstadt: WBG.

Hegel, Georg Wilhelm Friedrich. 1955. Grundlinien der Philosophie des Rechts, 4th ed. Hamburg: Meiner. First published 1821.

Hoesch, Matthias. 2016. Allgemeine Hilfspflicht, territoriale Gerechtigkeit und Wiedergutmachung: Drei Kriterien für eine faire Verteilung von Flüchtlingen- und wann sie relevant warden. In Welche und wie viele Flüchtlinge sollen wir aufnehmen? Philosophische Essays. Edited by Thomas Grundmann and Achim Stephan. Stuttgart: Reclam, pp. 15-29.

Hofmann, Bianca. 1999. Grundlagen und Auswirkungen des völkerrechtlichen Refoulement-verbotes. Potsdam: MRZ, Available online: https: //publishup.uni-potsdam.de/opus4-ubp/frontdoor/deliver/index/docId/4857/file/SGM03.pdf (accessed on 3 November 2020).

Horn, Christoph. 2006. Güterabwägung. In Handbuch Ethik, 2nd ed. Edited by Marcus Düwell, Christoph Hübenthal and Micha H. Werner. Stuttgart: J. P. Metzler, p. 393.

International Organization for Migration (IOM). 2018. World Migration Report 2018. Switzerland: IOM, pp. 32, 71. Available online: http:/ / publications.iom.int/system/files/pdf/wmr_2018_en.pdf?language=en (accessed on 3 November 2020).

Jakob, Christian, and Simone Schlindwein. 2017. Diktatoren als Türsteher Europas. Wie die EU ihre Grenzen nach Afrika Verlagert, 2nd ed. Berlin: Ch. Links.

Kant, Immanuel. 1786. Grundlegung zur Metaphysik der Sitten, 2nd ed. Riga: Hartknoch.

Kant, Immanuel. 1797. Metaphysik der Sitten. Tugendlehre Königsberg: Nicolovius.

Keil, Rainer. 2015. Asyl als Menschenrecht. In Gesellschaftliche Herausforderungen des Rechts. Gedächtnisschrift Rittstieg. Edited by Markus Krajewski, Mathias Reuß and Tarik Tabbata. Baden-Baden: Nomos.

Koch, Anne, Anette Weber, and Isabelle Werenfels. 2018. Migrationsprofiteure. Autoritäre Staaten in Afrika und das europäische Migrationsmanagement, SWP-Studie 3. Berlin: SWP, Available online: https://www.swp-berlin.org/fileadmin/contents/products/studien/ 2018S03_koc_web_wrf.pdf (accessed on 3 November 2020).

Krammer, Robert. 2012. Menschenwürde und Art. 3 EMRK: Grundrechtsverletzungen in Form von Polizeigewalt und Haft. Wien: Jan Sramek.

Kuosmanen, Jaako. 2012. Global protection of the right to asylum and partial compliance. Global Justice 5: 46-55. [CrossRef]

Kuosmanen, Jaakko. 2013. Perfecting Imperfect Duties: The Institutionalisation of a Universal Right to Asylum. Journal of Political Philosophy 21: 24-43. [CrossRef]

Ladwig, Bernd. 2011. Gerechtigkeitstheorien als Einführung. Hamburg: Junius.

Ladwig, Bernd. 2012. Offene Grenzen als Gebot der Gerechtigkeit? In Migration und Ethik. Edited by Andreas Cassee and Anna Goppel. Münster: Mentis.

Larenz, Karl. 1970. Hegels Zurechnungslehre und der Begriff der objektiven Zurechnung. Aalen: Scientia. First published 1927.

Lumer, Christoph. 2004. Vom Primat der Werte-Wertethik versus Pflicht- und Tugendethik. In Wertethik und Werterziehung. FS Arnim Regenbogen. Edited by M. Mokrosch and E. Franke. Göttingen: Vandenhoek \& Ruprecht, Available online: http: / / www.lumer.info/wp-content/uploads/2012/04/A062_Lumer_VomPrimatDerWerte.pdf (accessed on 3 November 2020).

Mann, Itamar. 2020. The Right to Perform Rescue at Sea: Jurisprudence and Drowning. German Law Journal 21: 598-619. [CrossRef]

Märker, Alfredo, and Stephan Schlothfeldt, eds. 2002. Was schulden wir Flüchtlingen und Migranten? Grundlagen einer gerechten Zuwanderungspolitik. Wiesbaden: SpringerVS. [CrossRef]

McNauthton, David, and Piers Rawling. 1998. On Defending Deontology. Ratio 11: 37-54. [CrossRef]

Mill, John Stuart. 2001. On Liberty. Kitchener: Batoche. First published 1859.

Miller, David. 2016. Strangers in our Midst. The Political Philosophy of Immigration. Cambridge: HUP. [CrossRef]

Mona, Martino. 2007. Das Recht auf Immigration. Rechtsphilosophische Begründung eines originären Rechts auf Einwanderung im liberalen Staat. Basel: Helbing Lichtenhahn.

Myers, Norman. 2002. Environmental Refugees: A Growing Phenomenon in the 21st Century. Philosophical Transactions of the Royal Society B 357 (2002). p. 609. Available online: http:/ / rstb.royalsocietypublishing.org/content/357/1420/609 (accessed on 3 November 2020).

Nagel, Thomas. 2000. Mortal Questions. Cambridge: CUP Canto Edition. 
Nida-Rümelin, Julian. 2017a. Über Grenzen denken. Eine Ethik der Migration. Hamburg: Körber-Stiftung.

Nida-Rümelin, Julian. 2017b. Zur Legitimität von Staatlichkeit: Eine kosmopolitische Kritik offener Grenzen. DZPhil 65: 709-26. [CrossRef]

Nussbaum, Martha. 2011. Creating Capabilities. The Human Development Approach. Cambridge: Belknap.

Obermayer, Elvira. 2017. Glück. Konzept und Aktualität der aristotelischen Eudaimonia. Nordhausen: Bautz.

Ott, Konrad. 2016. Zuwanderung und Moral. Stuttgart: Reclam.

Ott, Konrad, and Moritz Johannes Riemann. 2018. On Flight Reasons-Persecution, Escape, Displacement. In How to Deal with Refugees? Europe as a Continent of Dreams. Edited by Gerhard Besier and Katarzyna Stoklosa. Berlin: Lit, pp. 15-39.

Papastravridis, Efthymios. 2020. The European Convention of Human Rights and migration at Sea: Reading the "Jurisdictional Threshold" of Convention Under the Law of the Sea Paradigm. German Law Journal 21: 417-35. [CrossRef]

Parfit, Derek. 1984. Reasons and Persons. Philosophy and Phenomenological Research 47: 311-27. [CrossRef]

Penz, Peter. 2010. International Ethical Responsibilities to "Climate Change Refugees". In Climate Change and Displacement: Multidisciplinary Perspectives. Edited by Jane McAdam. Oxford: Hart Publishing.

Pfaff, Isabel, and Nikolaus Piper. 2016. Ursache oder Lösung. Süddeutsche.de of 23/11/2016. Available online: http://www. sueddeutsche.de/wirtschaft/2.220/freihandelsabkommen-ursache-oder-loesung-1.3262864 (accessed on 3 November 2020).

Platon. 1966a. Gorgias. Translated into German by Friedrich Schleiermacher, Numbered According to the Stephanus Edition (1578). Reinbek: Rowohlt.

Platon. 1966b. Politeia. Translated into German by Friedrich Schleiermacher, Numbered According to the Stephanus Edition (1578). Reinbek: Rowohlt.

Pogge, Thomas W. 2002. Migration und Armut. In Was schulden wir Flüchtlingen und Migranten? Grundlagen einer gerechten Zuwanderungspolitik edited by Alfredo Märker and Stephan Schlothfeldt. Wiesbaden: SpringerVS, pp. 110-26. [CrossRef]

Pogge, Thomas W. 2008. World Poverty and Human Rights. Cosmopolitan Responsibilities and Reforms, 2nd ed. Cambridge: Polity Press.

Quante, Michael. 1993. Hegels Begriff der Handlung. Stuttgart: Fromann Holzboog.

Rennert, Klaus. 2017. Hannah Arendt, das Asylrecht und die Menschenwürde. Baden-Baden: Nomos.

Richter, Dagmar. 2016. Quasi-Asyl als Menschenrecht. In Asyl und Migration in Europa-Rechtliche Herausforderungen und Perspektiven. Edited by Marc Bungenberg, Thomas Giegerich and Torsten Stein. ZEuS Sonderband and Baden-Baden: Nomos.

Risse, Mathias. 2009. The Right to Relocation: Disappearing Islands Nations, and Common Ownership of the Earth. Ethics $\mathcal{E}$ International Affairs 23: 281-300. [CrossRef]

Rochel, Johan. 2020. How to Justify the Competence to Control Immigration? ARSP 106: 189-213. [CrossRef]

Rosenbaum, Thane. 2011. The Myth of Moral Justice. Why Our Legal System Fails to Do What's Right. New York: HarperCollins.

Rössler, Beate. 2017. Autonomie. Ein Versuch über das gelungene Leben. Berlin: Suhrkamp.

Schlothfeldt, Stephan. 2002. Ökonomische Migration und globale Verteilungsgerechtigkeit. In Was schulden wir Flüchtlingen und Migranten? Grundlagen einer gerechten Zuwanderungspolitik. Edited by Alfredo Märker and Stephan Schlothfeldt. Wiesbaden: SpringerVS, pp. 93-109. [CrossRef]

Schnabel, Ulrich. 1999. Die Würde des Affen. In ZEIT-Online (11.11.1999). p. 4. Available online: http://www.zeit.de/1999/46/Die_ Wuerde_des_Affen / (accessed on 3 November 2020).

Schroth, Jörg. 2009. Deontologie und die moralische Relevanz der Handlungskonsequenzen. ZphilForsch 63: 55-75. [CrossRef]

Shamsuddoha, Muhammad (Md.). 2009. Climate Change Induced Forced Migrants. In Need of a Dignified Recognition under a New Protocol; Dhaka: Equity and Justice Working Group. Available online: http://www.glogov.org/images/doc/equitybd.pdf (accessed on 3 November 2020).

Singer, Peter. 1972. Famine, Affluence, and Morality. Philosophy and Public Affairs 1: 229-43.

Singer, Peter. 1993. Insiders and Outsiders. In Practical Ethics, 2nd ed. Cambridge: CUP, p. 247.

Singer, Peter. 2011. Practical Ethics, 3rd ed. Cambridge: CUP.

Singer, Peter. 2015. Escaping the Refugee Crisis. Available online: https://www.project-syndicate.org/commentary/escaping-europerefugee-crisis-by-peter-singer-2015-09 (accessed on 3 November 2020).

Steinvorth, Ulrich. 2008. Globalisierung-Arm und Reich. In Kolleg Praktische Philosophie. Edited by Franz Josef Wetz. Vol. 4: Recht auf Rechte. Stuttgart: Reclam, pp. 170-207.

Strohmayr, Simone. 1998. Menschenwürde und Strafvollzug. Cottbus: Doctorial dissertation, University of Cottbus 1998.

Thomson, Judith Javis. 1971. A Defense of Abortion. Philosophy \& Public Affairs 1: 47-66.

Thurin, Oliver. 2009. Der Schutz des fremden vor rechtswidriger Abschiebung. Das Prinzip des Non-Refoulement nach Artikel 3 EMRK. Wien: Springer.

Tiedemann, Paul. 1991. Das Recht der Steuerverweigerung aus Gewissensgründen. Hildesheim: Olms.

Tiedemann, Paul. 2016a. The Ambivalence of Current Refugee Law Between Solidarity with 'Friends' and Solidarity with 'Human Beings'. JHRW 1: 175-83. [CrossRef]

Tiedemann, Paul. 2016b. Gefahrendichte und Judiz-Versuch einer Rationalisierung. ZAR 36: 53-60.

Tiedemann, Paul. 2017. Migration im Naturzustand. Überlegungen zum No-Border-Postulat. JRE 25: $125-67$.

Tiedemann, Paul. 2018a. Working Paper I: The No-Border-Postulate. Available online: https://ssrn.com/abstract=3281100 (accessed on 3 November 2020). 
Tiedemann, Paul. 2018b. Flüchtlingsrecht. Die materiellen und verfahrensrechtlichen Grundlagen, 2nd ed. Berlin and Heidelberg: Springer. [CrossRef]

Tiedemann, Paul. 2018c. Solidarity. In Encyclopedia of the Philosophy of Law and Social Philosophy. Edited by Mortimer Sellers and Stephan Kirste. Houten: SpringerLink. [CrossRef]

Tiedemann, Paul. 2020. Philosophical Foundation of Human Rights. Cham: Springer. [CrossRef]

Trapp, Rainer W. 1989. Systematische Klassifikation und vergleichende Betrachtung der wichtigsten Ethiktypen unter dem Gesichtspunkt ihrer Eignung als allgemein akzeptable Handlungsrichtlinien. Grazer Philosophische Studien 35: 123-51.

Tugendhat, Ernst. 1995. The Moral Dilemma in the Rescue of Refugees. Social Research 62: 129-42.

Tugendhat, Ernst. 1997. Vorlesungen über Ethik, 4th ed. Frankfurt/M: Suhrkamp.

US Supreme Court. 1993. 509 U.S. 155. 156. Sale v. Haitian Centers Council. Available online: http://caselaw.findlaw.com/ussupreme-court/509/155.html (accessed on 3 November 2020).

Vaskovics, Lazlo A. 1995. Armut. In Staatslexikon, 7th ed. Edited by Görres-Gesellschaft. Freiburg: Herder, vol. 1, p. 342.

Wildt, Andreas. 2007. Milde Pflichten. Moralische Verpflichtungen ohne korrelative moralische Rechte anderer. DZPhil 55: 41-57. [CrossRef]

Wissenschaftlicher Dienst des Deutschen Bundestages (Wissenschaftlicher Dienst). 2016. Rechtliche Konsequenzen einer Behinderung von Seenotrettern. WD 2-3000-138/16. Berlin: Deutscher Bundestag, S. 6. Available online: https://www.bundestag.de/blob/485804 / fa7d773621d961efb70477f8f114c715/wd-2-138-16-pdf-data.pdf (accessed on 3 November 2020).

Wyman, Katrina M. 2013. Are we morally obligated to Assist Climate Change Migrants? LEHR 7: 185-212. [CrossRef]

Young, Iris Marion. 2006. Responsibility and Global Justice. A social Connection Model. Social Philosophy and Policy 23: 102-30. [CrossRef] 